\title{
Neanderthal and Carnivore Occupations in Unit II from the Upper Pleistocene Site of Ramandils Cave, (Port-la-Nouvelle, Aude, France).
}

${ }^{a}$ UMR7194 HNHP, Université de Perpignan Via Domitia, 52 Avenue Paul Alduy, 66100 Perpignan, France.

${ }^{b}$ UMR7194 HNHP, EPCC-Centre Européen de Recherche Préhistorique, Avenue Léon Jean Grégory, 66720 Tautavel, France.

${ }^{c}$ UMR7194 HNHP, Département Homme et Environnement, Muséum national d'Histoire naturelle, Musée de l'Homme, 75116 Paris, France

*Corresponding author: lucile.rusch@cerptautavel.com

\section{ABSTRACT}

The northwestern Mediterranean coast includes varied environment with abundant faunal and lithic resources exploited during the Upper Pleistocene. In this area, the Ramandils Cave (Port-la-Nouvelle, Aude, France) records Middle Palaeolithic levels dating to Marine Isotope Stage (MIS) 5. Evidence of Neanderthal occupations are observed throughout the sequence; with numerous lithic industries, burnt faunal remains, marine shells, and few human bones. In unit II, the richest one, lithic exploitation strategies are linked to the availability of major areas of flint supply implying a defined mobility pattern. Several archaeostratigraphic levels have been individualised, with ungulate remains affected by human and carnivore predation, involving alternated occupations of the cave during different periods. By confronting studies on origin and management of lithic raw material with taphonomical and zooarchaeological data of large mammals, we attempt to gain a better understanding of the site function, occupation duration, and regional mobility pattern in unit II of Ramandils Cave.

Keywords: Neanderthal occupations, Upper Pleistocene, large mammals, lithic industry, mobility pattern, site function

\section{Introduction}

The northwestern Mediterranean coast records several Middle Palaeolithic sites, correlated between Marine Isotopic Stage (MIS) 5 to 3, with recurrent Neanderthal occupations, such as Ramandils cave, Crouzade cave, Tournal cave, and the rockshelter of Les Canalettes (Bischoff et al., 1988; Cochard et al, 2012; Daujeard et al, in Djindjian et al, 2018; Magniez, 2010; Rusch et al., 2019; Saos, 2003; Saos et al, 2016, 2017; Valladas \& Joron, 1993; Yokoyama et al., 1987a). Faunal associations reflect climatic conditions between these transition periods as well as human and carnivore behaviours, frequently recorded in the same assemblages during Upper Pleistocene (Brugal et al., 2017; Costamagno et al., 2005; Daujeard et al, 2016, Discamps et al., 2012; Magniez, 2010; Rendu, 2007; Saladié et al., 2018, among many others). This involves representation, with different intensities and frequencies, of zooarchaeological and taphonomic markers on ungulate carcasses, implying various subsistence behaviors of these two types of predators. Occupation and Mobility patterns are accessible through regional studies (Daujeard \& Moncel, 2010; Daujeard et al, 2016; Grégoire, 2012; Lebègue et al, 2010; Patou-Mathis, 2000; Szmidt, 2003; Valensi \& Psathi, 2004; among many others), by taking into consideration raw material resources available in the territory, as well as faunal remains and lithic tools analyses found in sites. Three major occupation modes are discerned in this chronological period, long-term residential camps with predominantly anthropogenic accumulation, short-term regular camps that can be occupied alternately with carnivore occupations, and brief stopover as bivouacs, such as highlighted in South of France around Mediterranean coast and in the Rhône Valley (Daujeard \& Moncel, 2010; Daujeard et al., 2016; Magniez, 2010; Saos et al., 2016). 
The coastal context of Ramandils cave (Port-la-Nouvelle, Aude, France) with the proximity of various ecosystem and major areas of flint supply point out this site as a key sequence for mobility studies during upper Pleistocene. Last excavations (Boutié et al, 1998) have yielded several occupation levels with both Neanderthal and carnivore activities, mainly represented by numerous lithic tools, burnt bones, marine shells, and coprolite deposits. Recent studies on large mammal remains, palynological analyses of coprolites and new radiometric dating were conducted (Rusch et al., 2019), and allow to correlate the sequence to the end MIS 5. The results highlighted temperate climate with forest, open (grasslands), and rocky landscapes. The unit II, the richest one of Ramandils Cave, is chosen here for the study of the successives occupations on this strategic place. Archaeostratigraphic approach in progress permitted to individualise several occupation levels in this unit, with evidence of human and carnivore activities. Thereby, thanks to archaeozoological parameters, using mortality patterns, seasonality by large mammal spectrum, anatomical distribution, and taphonomic traces studies, in addition with lithic raw material supply modalities and lithic production technological processes, we will attempt to interpret subsistence strategies and economical scheme of the lithic production. These feature combinations will allow us to gain a better understanding of mobility patterns and site function.

\section{Site presentation}

Ramandils Cave (Port-la-Nouvelle, Aude department, southern France), is located $30 \mathrm{~km}$ south of Narbonne (fig. 1a), altitude $1.5 \mathrm{~m}$, and separated from the current Mediterranean shoreline by $1,400 \mathrm{~m}$ of lagoon deposits (fig. 1b). This east-facing cavity, towards the sea, is formed at the bottom of an Urgo-Aptian limestone hill, called Cap Romarin, east of the first Corbières massif foothill. This cave nowadays has a collapsed ceiling on the most part.

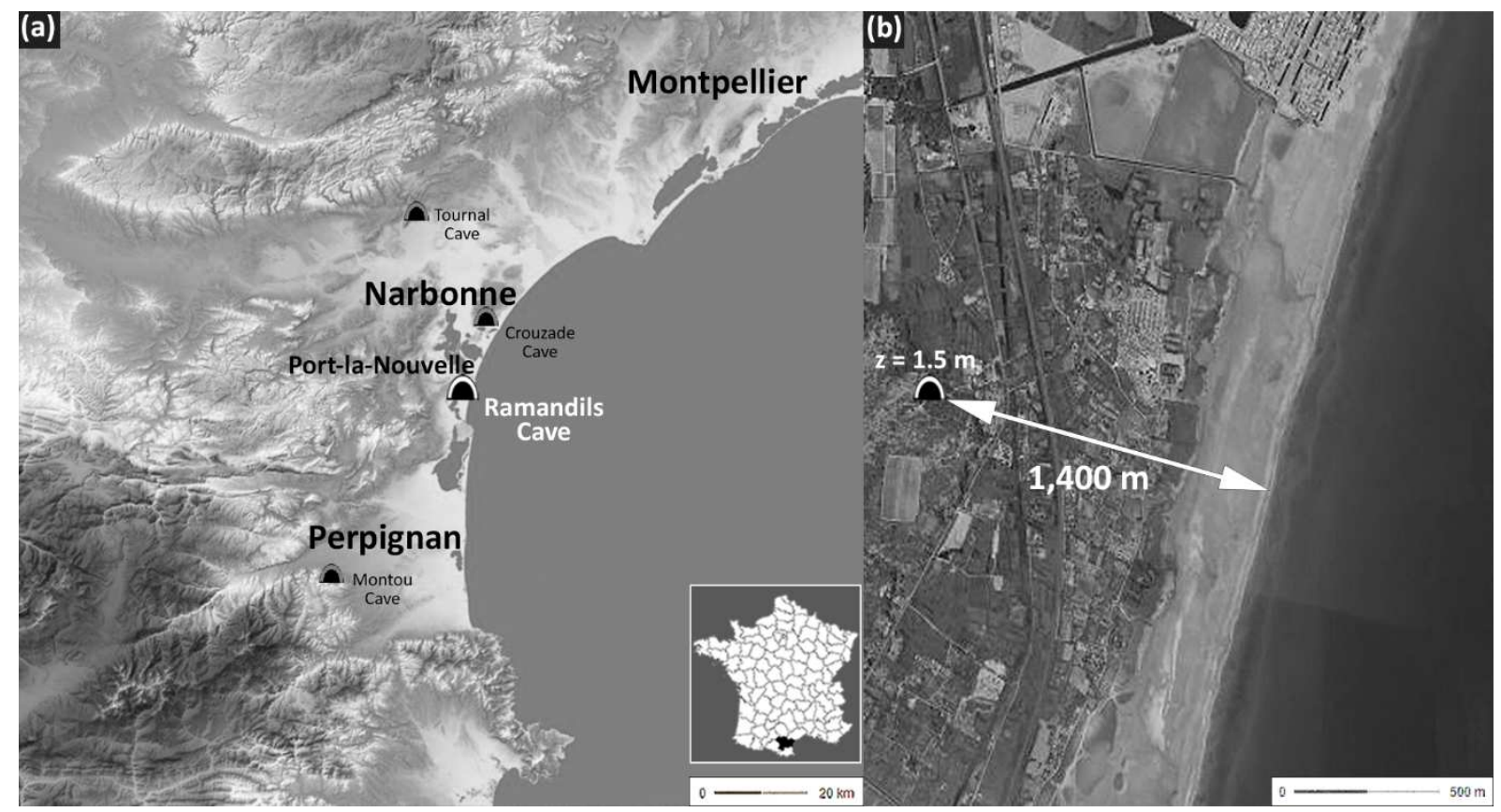

Fig. 1: Ramandils Cave locations: (a) raised-relief map with upper Pleistocene sites and (b) aerial photography (modified according www.geoportail.gouv.fr) 
The site was discovered in 1925 by Théophile Héléna (Grégoire, 2011). Planned yearly excavations were directed by Paul Boutié between 1983 and 1994 (Boutié et al, 1998), on more than $50 \mathrm{~m}^{2}$, according to systematic methods and based on a grid reference to record 70 Cartesian data (fig. 2).

\section{(a) $|\mathbf{E}| \mathbf{F}|\mathbf{G}| \mathbf{H}|\mathbf{I}| \mathbf{J}|\mathbf{K}| \mathbf{L}|\mathbf{M}| \mathbf{N}|\mathbf{O}| \mathbf{P} \mid$}
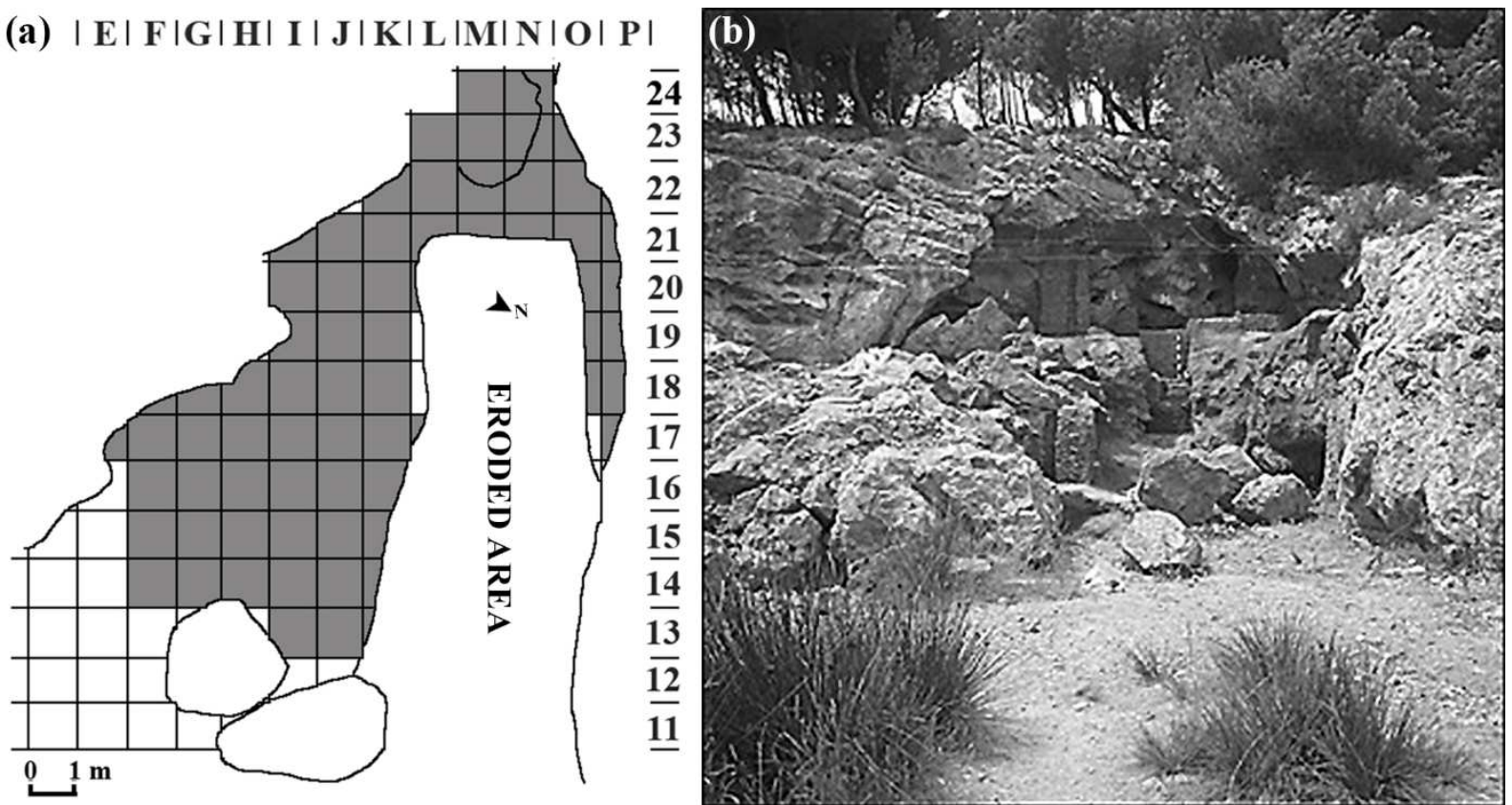

Fig. 2: (a) Grid reference with excavated areas in gray, each one-meter squared area is distinguished by a letter (E to $P$ ) correlated with a number (11 to 24). (b) East view of the cave (modified according to Boutié, 1990 and Rusch et al, in press, photo credit: P. Boutié, Centre Européen de Recherches Préhistoriques, Tautavel).

The cave, more than $5 \mathrm{~m}$ high, was completely filled with sediment, partially eroded in the lower part by an active natural spring (fig. 3). The stratigraphic sequence firstly records, at the bottom, a marine level with marine shells dated by Electron Spin Resonance (ESR) method to $128 \pm 15 \mathrm{ky}$ (Yokoyama et al., 1987) to the last Thyrrhenian transgression. Secondly, continental deposits are individualised (Kabiri, 1993) into five stratigraphic units (numbered I to V), containing among others, equids teeth, dated by ESR/U-Th (Uranium-Thorium) method between $94 \pm 7 \mathrm{ky}$ (unit V) and $77 \pm 6 \mathrm{ky}$ (unit I) to the end of Marine Isotope Stage 82 (MIS) 5 (Rusch et al., 2019).

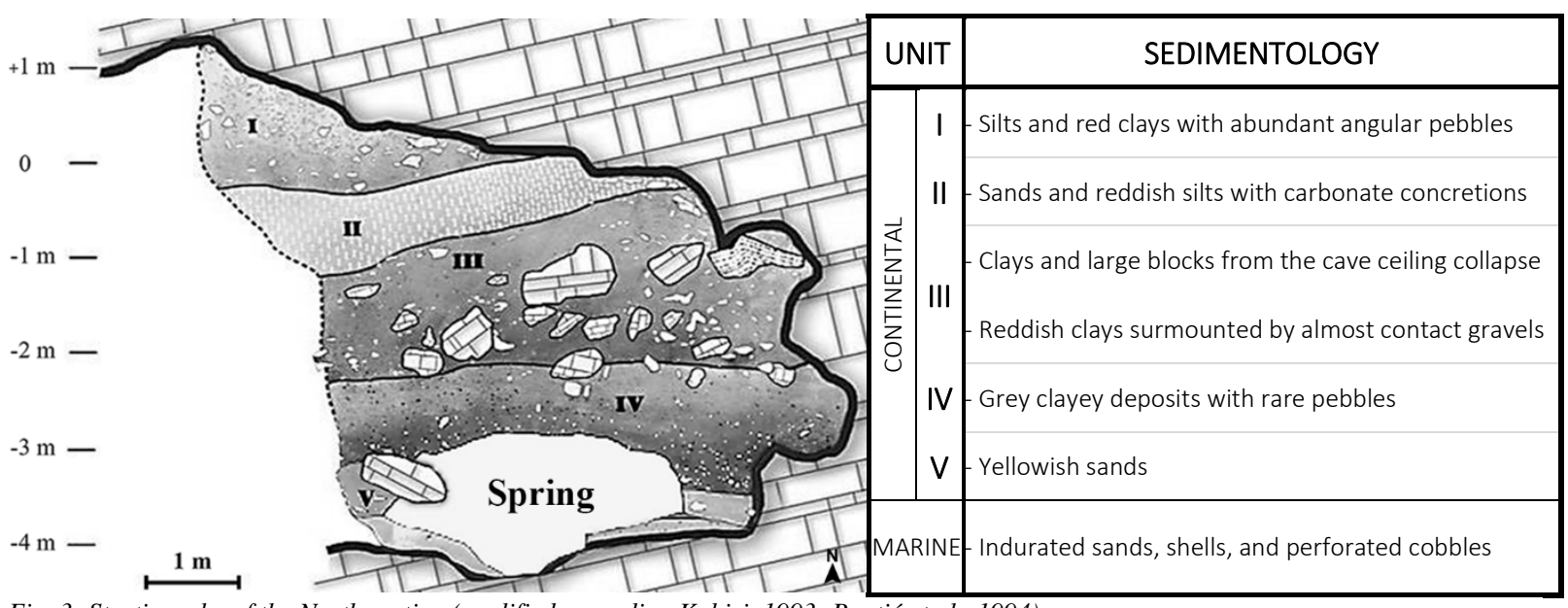

Fig. 3: Stratigraphy of the North section (modified according Kabiri, 1993; Boutié et al., 1994). 
Mousterian occupations are recorded for all continental levels, mostly represented by lithic industries (29,994 pieces) corresponding to a Typical Mousterian (Molès, 2008). The peculiarity of this lithic collection is that all pieces have very small dimensions. The unit II levels have 15,832 lithic pieces, of which $68.4 \%$ are less than $15 \mathrm{~mm}$ and thus generally uncoordinated. This is the richest stratigraphic unit of the site.

This collection contains $0.7 \%$ of cores, $20.9 \%$ of flakes, $5.9 \%$ of blades. The production modes are mainly Levallois and SSDA (39.7\% each). Among the Levallois systems, the Lineal $(52.7 \%)$ is the most represented followed by the orthogonal recurrent modality $(24.6 \%)$ and the recurrent centripetal ones $(20.6 \%)$. The cores on flakes (kombewa production) represents $6.9 \%$ and testify to a secondary chaine opératoire on the initial productions already of small dimensions (tab. 1) as a clear ramified flint exploitation strategy (Bourguignon et al., 2004). Discoids are rare (3.4\%). The remainings 10, $3 \%$ are indeterminate knapping systems. The reduction sequence on flint is totally represented into the site from the first steps of preparing cores, through the production of blanks by various methods (Levallois dominant, followed by SSDA and discoide methods) until the retouching process to produce tools on 99 flakes or blades and ramification of a part of the Levallois production, resulting in a 100 microlithisation of the production. The larger flakes were selected to produce flake tools. Tool percentage is low $4.8 \%$. Flake tools are mainly side-scrapers $(48 \%)$, followed by denticulates $(20 \%)$ and notches $(13 \%)$. A large part of the flake production was not retouched on tools.

\begin{tabular}{|c|c|c|c|c|c|c|c|c|}
\hline & $\begin{array}{l}\text { PRINCIPAL } \\
\text { RAW } \\
\text { MATERIAL }\end{array}$ & ORIGIN & MATRIX & $\begin{array}{c}\text { INPUT } \\
\text { MODALITY }\end{array}$ & $\begin{array}{l}\text { SECONDARY RAW } \\
\text { MATERIAL }\end{array}$ & ORIGIN & MATRIX & $\begin{array}{c}\text { INPUT } \\
\text { MODALITY }\end{array}$ \\
\hline \multirow[t]{3}{*}{$\begin{array}{l}\text { RAMANDILS } \\
\text { UNIT II }\end{array}$} & flint & semi-local & blocks, slabs & $\begin{array}{l}\text { raw blocks, } \\
\text { prepared } \\
\text { blocks }\end{array}$ & $\begin{array}{l}\text { quartzite, } \\
\text { chert, } \\
\text { limestone }\end{array}$ & semi local & pebble & whole \\
\hline & $\begin{array}{l}\text { REDUCTION } \\
\text { SEQUENCE }\end{array}$ & $\begin{array}{c}\text { DEFICIT } \\
\text { PRODUCT }\end{array}$ & $\begin{array}{l}\text { PRODUCTION } \\
\text { GOAL }\end{array}$ & $\begin{array}{l}\text { SECONDARY } \\
\text { METHOD }\end{array}$ & RAMIFICATION & $\begin{array}{l}\text { IMPORTANCE } \\
\text { OF TOOLS }\end{array}$ & $\begin{array}{l}\text { DOMINANT } \\
\text { TOOL }\end{array}$ & $\begin{array}{l}\text { ASSOCIATED } \\
\text { TOOL }\end{array}$ \\
\hline & $\begin{array}{c}\text { complete } \\
\text { for flint } \\
\text { partial for } \\
\text { other raw } \\
\text { material }\end{array}$ & $\begin{array}{l}\text { retouched } \\
\text { tools on } \\
\text { flakes }\end{array}$ & flakes (micro) & SSDA & yes & low & scraper & denticulate \\
\hline
\end{tabular}

Tab. 1: Main techno-economic characteristics of the unit II lithic assemblage (according to data from Moles, 2008).

Faunal remains (14,927 remains) are represented by large mammals, (Gerber, 1973; Banès 1996, 1998; Rusch et al., 2019), birds (Vilette in Boutié, 1993), lagomorphs and microvertebrates (Percie-du-Sert, 1992) with terrestrial (André in Boutié, 1993) and marine shells (Cataliotti-Valdina in Boutié, 1990; Celiberti \& Moigne in Saos et al., 2016). In unit II, three fragmented human teeth were discovered (Chevalier \& Bécam in Saos et al., 2016), without specific attribution or burial context. 


\section{Material and methods}

All of the material studied corresponds to coordinated objects that comes from Boutié's excavations, recorded according to the grid reference and stratigraphic subdivision in unit II.

\subsection{Archaeostratigraphy}

The Ramandils Cave has delivered an important archaeological material consisting of, unburnt and burnt bones, lithic tools, stones, shells, coprolites, ... representing about 31,000 coordinated objects. The first step is to create a database from the excavation notebooks and to validate the data before adding the faunal and lithic remains. The second step is to realize vertical sections of the objects along the transverse and longitudinal axes of the cave. In Ramandils Cave, the archaeological remains are so numerous that profiles were made every $10 \mathrm{~cm}$. It is then possible to begin the individualization of archaeological levels.

The profiles will be cross-referenced before highlighting the lower and upper limits of each occupation level. For the study of an excavation zone, of a square meter, it is thus proceeded with a hundred of cross-checks. Once, the limits of occupation levels are defined, each object is assigned a soil name (Pois, 1998, 1999). In unit II 6 levels are defined in unit II: S8, S9, S10, S11 and S12.

\subsection{Study of lithic Raw Material and their Origin}

The raw materials of the whole unit II were petrographically determined on a macroscopic basis and classified by category of rocks. Flints were characterized by the description of their microfacies with binoculars and then close to the known petrographical facies of the Languedoc-Roussillon repository of sedimentary siliceous rocks. This repository (Grégoire et al., 2010), set up in the framework of a PCR program, available at the European Center for Prehistoric Research at Tautavel was used as a reference for identifying sources. Following this method,-categories of rocks were identified in unit II and have been linked to potential sources (Boutié et al, 1998; Grégoire, 2000). From these identifications, a territory can be drawn and hypotheses of supply strategies can be proposed in relation to the settlement systems of territories by these nomadic peoples (Grégoire, 2012).

\subsection{Zooarchaeology}

Taxonomic and anatomical identifications were made from the reference collection of the European Center for Prehistoric Research at Tautavel, following the relevant literature (Barone, 1999; Pales \& Garcia, 1981; Schmid, 1972; Varela \& Rodriguez, 2004, among many others). The Number of Remains (NR), the Number of Identified Specimens (NISP), and the Minimum Number of Individuals (NMI) by combination were calculated (Grayson, 1984; Klein \& Cruz-Uribe, 1984; Lyman, 1994, 2008; Moigne, 1983; Poplin, 1981). The assessment of post-depositional modifications (Lyman, 1994) was conducted for diagenetic processes study (tab. 2) analysing steps of concretion, oxidation (manganese or iron impregnations), 


\begin{tabular}{|c|c|c|c|c|c|c|c|c|c|}
\hline & & \multicolumn{8}{|c|}{ Unit II levels } \\
\hline & & \multicolumn{2}{|c|}{ S10 } & \multicolumn{2}{|c|}{ S11 } & \multicolumn{2}{|c|}{$\mathrm{S} 12$} & \multicolumn{2}{|c|}{ Total } \\
\hline \multirow{3}{*}{\multicolumn{2}{|c|}{$\begin{array}{c}\text { NR Total } \\
\text { Legible bone total } \\
\text { Illegible bone total }\end{array}$}} & 896 & $100 \%$ & 2233 & $100 \%$ & 548 & $100 \%$ & 3677 & $100 \%$ \\
\hline & & 819 & $91 \%$ & 2039 & $91 \%$ & 489 & $89 \%$ & 3347 & $91 \%$ \\
\hline & & 77 & $9 \%$ & 196 & $9 \%$ & 61 & $11 \%$ & 334 & $9 \%$ \\
\hline \multirow{3}{*}{ Concretion } & Legible bones (C1) & 224 & $25 \%$ & 612 & $27 \%$ & 152 & $28 \%$ & 988 & $27 \%$ \\
\hline & Illegible bones $(\mathrm{C} 2+\mathrm{C} 3)$ & 39 & $4 \%$ & 101 & $5 \%$ & 38 & $7 \%$ & 178 & $5 \%$ \\
\hline & $\begin{array}{c}\text { Total } \\
\end{array}$ & 263 & $29 \%$ & 713 & $32 \%$ & 190 & $35 \%$ & 1166 & $32 \%$ \\
\hline \multicolumn{2}{|c|}{ Oxides (Mn, Fe) } & 474 & $53 \%$ & 739 & $33 \%$ & 122 & $22 \%$ & 1335 & $36 \%$ \\
\hline \multirow{3}{*}{$\begin{array}{l}\text { Cortical bone } \\
\text { alteration }\end{array}$} & Legible bones (D1 +D2) & 620 & $69 \%$ & 1355 & $61 \%$ & 198 & $36 \%$ & 2173 & $59 \%$ \\
\hline & Illegible bones (D3) & 39 & $4 \%$ & 100 & $4 \%$ & 26 & $5 \%$ & 165 & $4 \%$ \\
\hline & \begin{tabular}{|l} 
Total \\
\end{tabular} & 659 & $73 \%$ & 1455 & $65 \%$ & 224 & $41 \%$ & 2338 & $63 \%$ \\
\hline \multicolumn{2}{|c|}{ Cracking (F1 +F2 +F3) } & 136 & $15 \%$ & 263 & $12 \%$ & 96 & $17 \%$ & 495 & $13 \%$ \\
\hline
\end{tabular}

Concretions are described with 3 steps. The first one $(\mathrm{C} 1)$ is slight and isolated spots; the second one (C2) is a fine cover on the complete bone and the third one (C3) corresponds to bone being inside the concretion. Only remains with the first step have apparent cortical bone, accounting for around $27 \%$ of NR. Remains with step 2 and 3, for between 4 and $7 \%$ of NR, have not legible surface and are therefore not eligible for study other taphonomic markers.

Oxide deposits, mainly manganese, are observed on more than a quarter of remain in S11 and S12, and on more than half in S10. This low pigmentation of remains reveals bone surface and other taphonomic markers.

Cortical bone alteration due to water circulation is divided-with 3 steps. The first one (D1) with thin dissolution cups and the second one (D2) with slight desquamation areas corresponds to bones with legible surface, noticed for 36\% of NR in S12 to $69 \%$ of NR in S10. The third step, with desquamation affecting a large part of cortical surface is not eligible for study biological markers, representing about $4 \%$ of NR.

Cracking is related to the fissuring process, also due to the water circulation. The first step is just a thin hair-like fissure, the second one has pronounced splits but the size of bones is not affected, and the third one has deep or severe cracking. All these steps reveal cortical bones with legible surface for around $13 \%$ of total NR

165 Legible bones, accounting for $91 \%$ of NR, are sorted according step criteria of concretion and cortical bone alteration, that can be combined on the same bone fragment.

167 Material fragmentation was noticed according to size class, in millimetres, and nature of 168 remains (fig. 4). In unit II, mainly pieces are less than $40 \mathrm{~mm}$ length, especially for bones 169 remains, taken into account in the study of human and carnivore impacts. For the long bones 170 of mains species, size class and the circumference of diaphysis fragments were noted as well 171 as the distribution of partial remains, with complete epiphysis, and whole bones (Bunn, 1983;

172 Villa and Mathieu, 1991). 


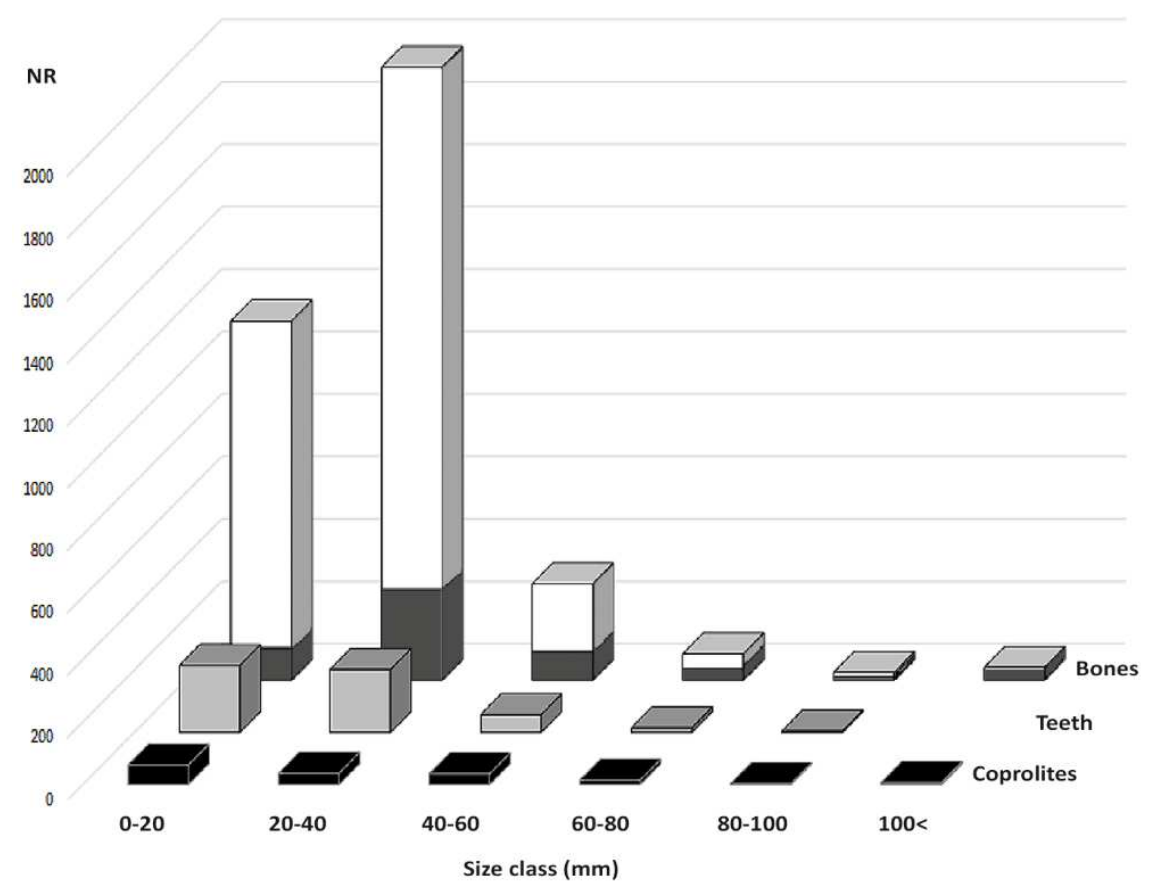

Fig. 4: Material length according class size $(\mathrm{mm})$ and nature of remains from unit II, for determinate (dark grey) and indeterminate (white) bones, teeth (light grey) and coprolites (black).

176 A biostratinomic alteration study was carried out on damage caused by roots, and rodents 177 (scraping) or carnivores tooth marks (pitting, furrowing, puncturing and scoring), with 178 digestion processes products by carnivores (Binfor, 1978, 1981; Blumshine, 1986; 179 Dominguez-Rodrigo \& Piqueras, 2003; Fosse 1996; Hayne, 1980; Klein and Cruz-Uribe, 180 1984). A part of coprolites is attributed to cave hyena, following morphological description 181 (Jouy-Avantin et al., 1999, 2003; Vivent, 1989), during palynological and parasitological 182 analyses (Lartigot-Campin \& Moné, 2017). Coprolites occurrence in unit II levels was used to 183 identify the zooarcheological sequence and carnivore activities in the site (Diedrich, 2012; 184 Discamps et al., 2012; Pineda, 2017).

185 Anthropic modifications of bones were studied (green fractures, cut marks, percussion marks, and technological applications of bones-essentially retouchers) according the 187 relevant literature (Binford 1981; Daujeard et al., 2018; Mallye et al., 2012; Noe-Nygaard 188 1989; Potts \& Shipman 1981; Shipman \& Rose 1983; Villa \& Mathieu, 1991) and a 189 microscope was used. Burnt remains were recorded for colour and burning localisation 190 (according Lebon, 2008).

191 Mortality profiles (Stiner, 1990) were based on age-at-death, established on eruption, 192 replacement, and dental wear, or epiphysis fusion. Seasonality was determined from the 193 current dates of ungulates birth (Azorit et al., 2002; Cornevin \& Lesbre, 1894; Guadelli, 1998; 194 Hayssen et al. 1993; Hillson, 1986; Magnell, 2007; Mariezkurrena, 1983; Pérez Ripoll, 1988). 195 In this regard, we only considered those species in which the age-at-death is estimated in 196 months corresponding to equids, bovids, cervids, and suids. 


\section{Results}

198

199

200

201

202

203

204

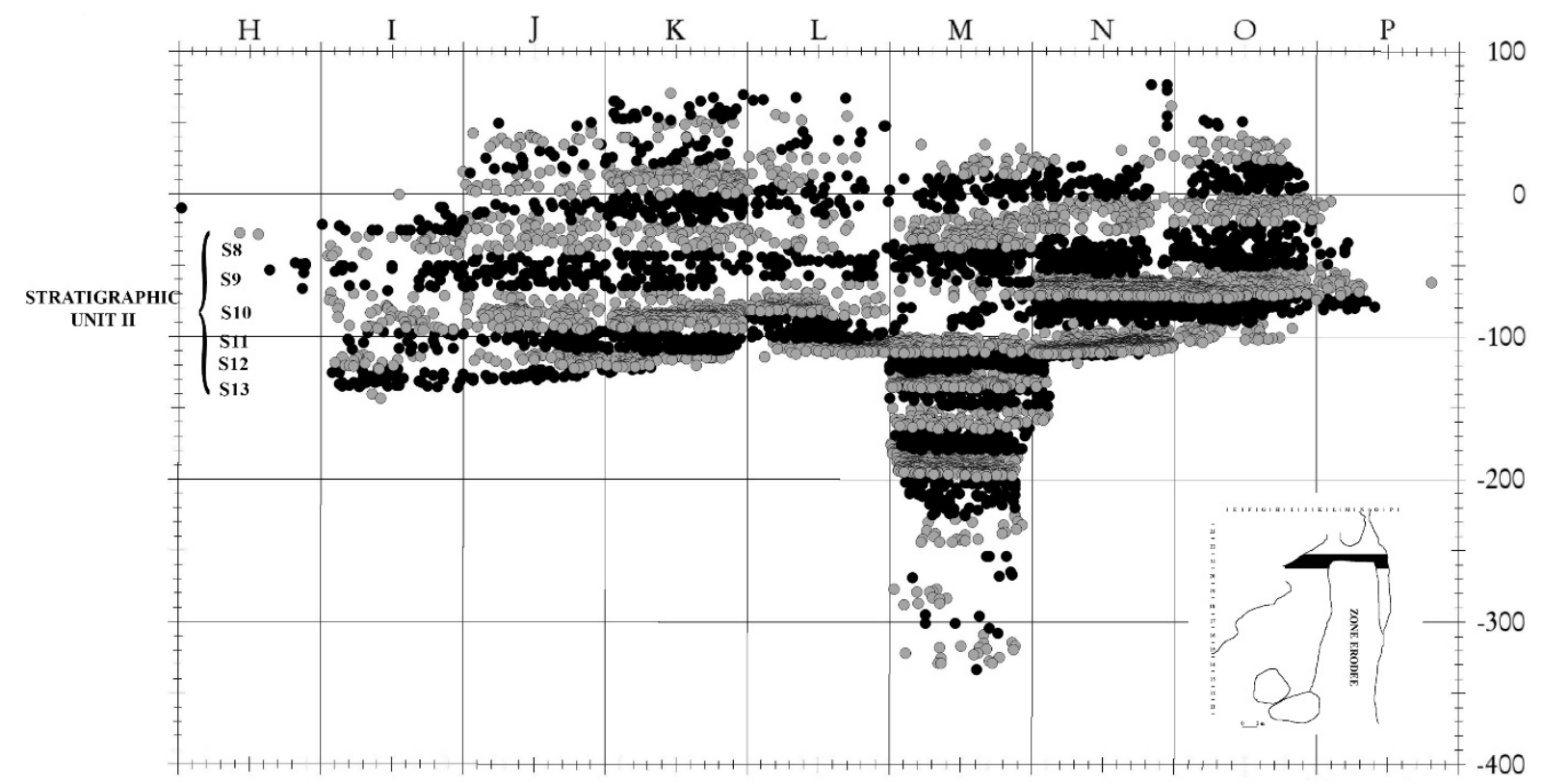

Fig. 5: Vertical section with all objects of the band 21. The alternance of grey and black is used to differentiate each occupation level

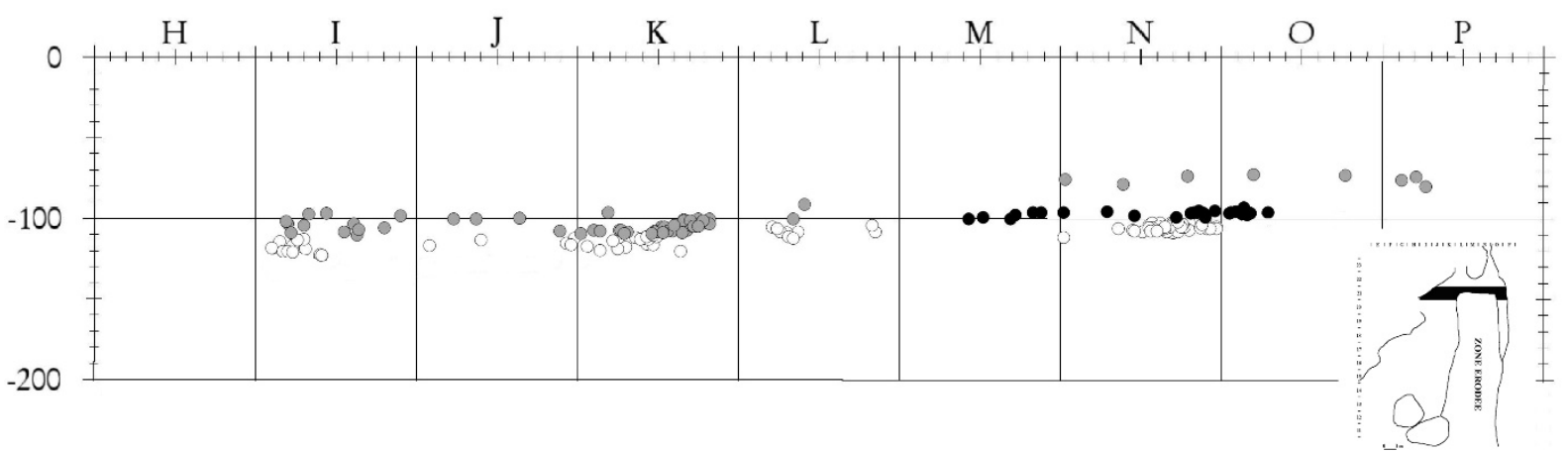

206

Fig. 6: Vertical section with S11 (grey), S12a (black) and S12 (white) in band 21. S12a corresponds to a coprolites bed. For an easier lecture, only thirty centimeters (between 0 and $30 \mathrm{~cm}$ ) are represented for occupation levels $S 11$ and $S 12$

S10, S11, and S12 are the richest levels, they contain respectively 4,267, 7,893 and 3,696 remains (tab. 3). The major part of the archaeological material is distributed into bands 21 to 24 (fig. 7). It is also in these three levels that coprolites are concentrated. Coprolites are

The study highlighted 26 occupation levels for the entire filling (fig. 5). In this article, we focus on stratigraphic unit II, the richest level which delivered almost 20,000 remains. Six occupation levels were defined in this unit, namely S8, S9, S10, S11, S12 and S13. However, the limits between units I and II and between units II and III still need to be clarified. The archaeological levels we are interested in for this study are mainly levels S10, S11 and S12. 


\begin{tabular}{|c|c|c|c|c|c|c|c|c|c|}
\hline Unit & $\begin{array}{c}\text { Occupation } \\
\text { level }\end{array}$ & Fauna & Coprolites & Shells & $\begin{array}{l}\text { Lithic } \\
\text { tools }\end{array}$ & Stones & $\begin{array}{c}\text { Human } \\
\text { bones }\end{array}$ & Others & Total \\
\hline \multirow{8}{*}{ II } & $\mathrm{S} 8$ & 158 & 2 & 10 & 119 & 27 & 0 & 2 & 318 \\
\hline & S9 & 943 & 5 & 48 & 834 & 158 & 0 & 14 & 2002 \\
\hline & S10 & 1988 & 7 & 55 & 1977 & 122 & 0 & 23 & 4172 \\
\hline & S11 & 3795 & 39 & 99 & 3637 & 91 & 2 & 131 & 7794 \\
\hline & S12a & 6 & 27 & 0 & 0 & 0 & 0 & 0 & 33 \\
\hline & S12 & 1772 & 43 & 44 & 1665 & 50 & 0 & 56 & 3630 \\
\hline & S13a & 0 & 12 & 0 & 0 & 0 & 0 & 0 & 12 \\
\hline & $\mathrm{S} 13$ & 145 & 3 & 2 & 148 & 15 & 0 & 7 & 320 \\
\hline \multicolumn{2}{|r|}{ Total } & 8807 & 138 & 258 & 8380 & 463 & 2 & 233 & 18731 \\
\hline
\end{tabular}

Tab. 3: Total archaeological material coordinated from stratigraphic unit II-

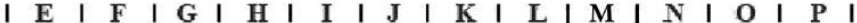

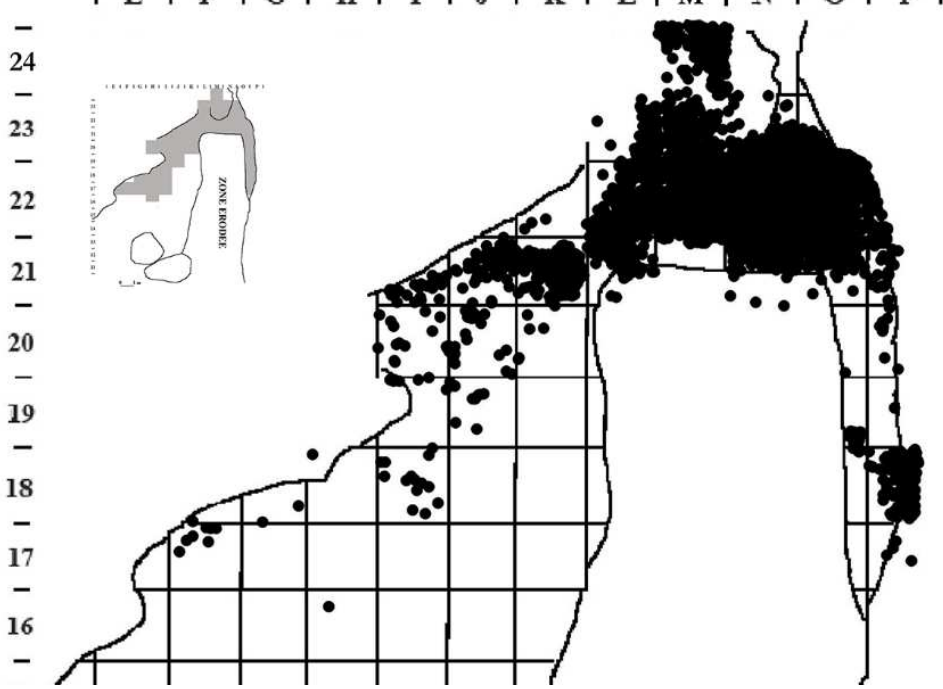

Fig. 7: Spatial distribution of the archaeological material in occupation level S11. Most of the remains are concentrated in band 21 to band 24.

The archaeological approach allows a finer study of the filling than that carried out from the stratigraphic units (Pois, 2000). At the level of the unit II, it was, indeed, impossible to perceive these coprolites beds. However, it is interesting to see these coprolite beds at the limit of human occupations. It should also be noted the presence of coprolites within an anthropic level that may reflect a short abandonment of the site by humans.

\subsection{Lithic Assemblages: Raw Material}

The lithic collection from the unit II were studied by Moles (Molès, 2008) with a technotypological approach and by Grégoire (Boutié et al., 1998; Grégoire, 2000) with a petroarcheological point of view. In this article, we have chosen to use the contribution of the lithic industries, especially raw materials to feed the multidisciplinary discussion about the function site and the mobility pattern of human groups. However, unlike fauna, the results from previous studies were not analysed according to the archaeostratigraphic division proposed here for unit II. A homogenization work is actually underway but general trends will therefore be proposed and discussed in relation with the archaeozoological data, offering at this stage a better study resolution. 
Ten different raw materials were used in the stratigraphic unit II, the richest one (tab. 4). This is the level with the most lithological diversity. Flint is the most widely used rock with 91.5\%. Other kinds of rocks are used like quartzite, chert, limestone, quartz, lydian, 235 sandstone, jasper, schist and hornfels.

\begin{tabular}{|c|c|}
\hline \multicolumn{2}{|c|}{ Unit II } \\
\hline Flint & $91.5 \%$ \\
\hline Quartzite & $4.0 \%$ \\
\hline Chert & $1.9 \%$ \\
\hline Limestone & $1.2 \%$ \\
\hline Quartz & $0.8 \%$ \\
\hline Hornfels & $0.2 \%$ \\
\hline Jasper & $0.1 \%$ \\
\hline Sandstone & $0.1 \%$ \\
\hline Schist & $0.1 \%$ \\
\hline Lydian & $0.1 \%$ \\
\hline Total & $100 \%$ \\
\hline
\end{tabular}

The flints are generally very alterated with a white or beige and total thick patina. Burnt artefacts are abundant (39.6\%) and make it difficult to identify flint categories.

Essentially represented by flint, siliceous rocks are largely in the majority (94\%). Quartzite is the second most used rock after flint, followed by limestone and quartz. Non-siliceous rocks $(6 \%)$ are represented by various raw materials, collected in the form of pebbles. These pebbles came from alluvial deposits, but also from the marine environment because of the proximity of the Mediterranean shore.

Thanks to some flint artefacts little altered or without any thermal impact, several types were recognized. All of them shows the main characteristics of the Miocene and more rarely the Oligocene regional facies, well known (Grégoire, 2010) on the Tertiary Narbonne-Sigean Basin around the site.

The study of the microfacies of these flints shows two main groups which correspond to both the stratigraphic upper Oligocene facies and the lower Miocene facies (Aquitanian).

The upper Oligocene facies is characterized by a mudstone texture slightly fossiliferous consisting of cryptocristallin micritic silica with hematites and frequent ferruginous impregnations as well as rare bioturbations. The Miocene flint shows a wackestone / packstone texture with charophytes (boiled stalks, oogones), gastropods and ostracods.

The sedimentary texture and the inclusions are reliable discriminating characters to distinguish the two stratigraphic facies and pinpoint their source in the current landscape within the Narbonne-Sigean basin (fig. 8). 
Concerning the most frequent flint, the poor quality of blanks used for debitage production, as well as the presence of charophytes remains visible at a macroscopic level, allows to eliminate the exploitation of high quality oligocene flints provided by the outcrops of Roquefort des Corbières (fig. 8, flint source $\mathrm{n}^{\circ} 4$ ), Indeed, Neanderthals have rarely used this rock which is attested in the site by only a few artefacts. The miocene flints (fig. 8, flint sources $n^{\circ} 1,2,3,5$ ), the most used, probably come from mostly tectonized blocks of the Presqu'île du Doul, Portel-des-Corbières or Hameau du Lac Miocene sources. Some cherts coming from the Cretaceous Corbières formation, at the north-west of the site (fig. 8, flint source $\mathrm{n}^{\circ}$ ), and from the nearest Jurassic formation at the north of the tertiary basin (fig. 8, flint source $n^{\circ} 7$ ), were also used in the unit II.

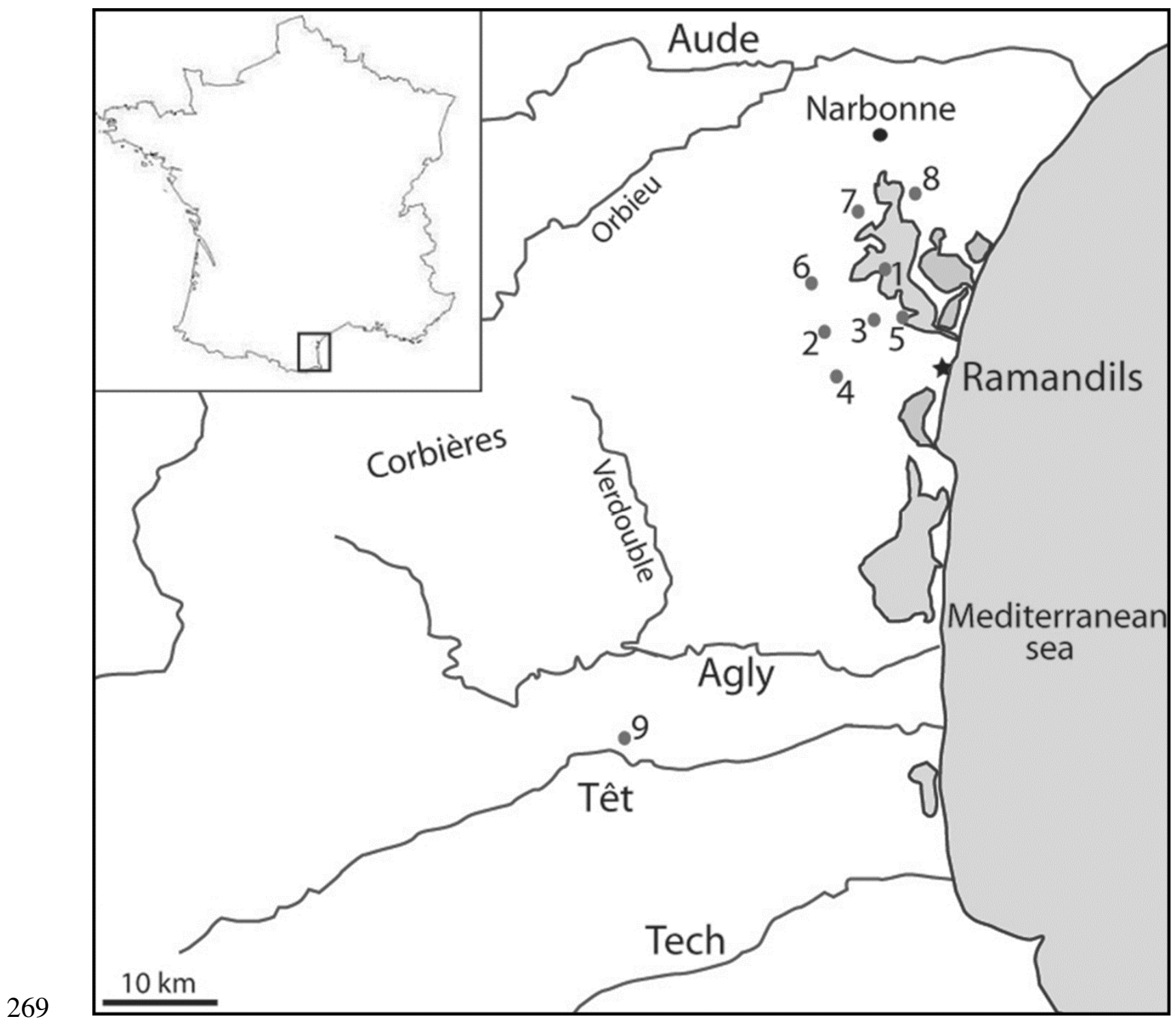

Fig. 8: Location of the lithic raw material and faunal sources on the local and semi-local territory around Ramandils Cave. $1:$ Presqu'île du Doul (Miocene flint), 2: Portel des Corbières (Miocene flint), 3: Hameau du Lac (Miocene flint), 4: Roquefort des Corbières (Oligocene flint), $5:$ Sigean (Miocene flint), $6:$ Plan du Couloubret (chert); $7:$ Hauts de Narbonne (chert), $8:$ Aude alluvial deposits (quartz, quartzite, limestone, hornfels, lydian, sandstone, schist), 9 : Têt alluvial deposits (jasper). 
Unit II of Ramandils Cave counts 4,058 NR of large mammals (without considering coprolites), with $91 \%$ distributed in levels S10, S11 and S12. Faunal study will allow to define the species spectrum and to characterise these three occupation levels.

\subsubsection{Species Composition}

The three levels count 3,682 total NR, corresponding to 653 NISP (tab. 5) with S11 as the richest level (2235 NR, 321 NISP). Faunal spectrum is mainly composed of ungulates (94\% NISP), dominated by red deer, Cervus elaphus (33\% total NISP), especially in S11 (36\% NISP) and S12 (33\% NISP), with horse, Equus f. germanicus (28\% total NISP), prevalent in S10 (33\% NISP). Moreover, European wild ass, Equus hydruntinus, aurochs, Bos primigenius, and wild boar, Sus scrofa, are well represented in these levels (each by $8 \%$ of total NISP).

Carnivores are generally rare (6\% NISP), particularly represented by cave hyena, Crocuta c. spelaea ( $2 \%$ NISP), cave lynx, Lynx spelaeus (1\% NISP), fox, Vulpes vulpes (1\% NISP), wolf, Canis lupus (0.6\% NISP), and cave beer, Ursus spelaeus (0.6\% NISP). Between S11 and S12, S12 a level is composed of carnivore remains (cave hyena, badger, Meles meles, and unspecified bear) with only one ungulate bone attributed to the horse.

At last, a significant number of indeterminate bones are recorded in S10, S11 and S12 mainly classify as small ungulates (2804 NR) according size and thickness criteria, that could indicate high bone fragmentation.

\begin{tabular}{|c|c|c|c|c|c|c|c|c|c|c|}
\hline \multirow[b]{2}{*}{ Total carnivores (NISP) } & \multicolumn{2}{|c|}{ S10 } & \multicolumn{2}{|c|}{ S11 } & \multicolumn{2}{|c|}{ S12a } & \multicolumn{2}{|c|}{ S12 } & \multicolumn{2}{|c|}{ Total } \\
\hline & 11 & $5.9 \%$ & 18 & $5.6 \%$ & 3 & $75 \%$ & 8 & $5.6 \%$ & 40 & $5.9 \%$ \\
\hline U. $\operatorname{arctos}$ & 1 & $0.5 \%$ & 1 & $0.3 \%$ & - & - & - & - & 2 & $0.3 \%$ \\
\hline U. spelaeus & 1 & $0.5 \%$ & 2 & $0.6 \%$ & - & - & 1 & $0.7 \%$ & 4 & $0.6 \%$ \\
\hline M. meles & - & - & 1 & $0.3 \%$ & 1 & $25 \%$ & - & - & 2 & $0.3 \%$ \\
\hline Lutrinae indet. & 1 & $0.5 \%$ & - & - & - & - & 1 & $0.7 \%$ & 2 & $0.3 \%$ \\
\hline C. lupus & - & - & 1 & $0.3 \%$ & - & - & 3 & $2.1 \%$ & 4 & $0.6 \%$ \\
\hline V. vulpes & 1 & $0.5 \%$ & 4 & $1.3 \%$ & - & - & 1 & $0.7 \%$ & 6 & $0.9 \%$ \\
\hline C. c. spelaea & 3 & $1.6 \%$ & 6 & $1.9 \%$ & 2 & $50 \%$ & 2 & $1.4 \%$ & 13 & $2.0 \%$ \\
\hline L. spelaeus & 4 & $2.1 \%$ & 2 & $0.6 \%$ & - & - & - & - & 6 & $0.9 \%$ \\
\hline F. silvestris & - & - & 1 & $0.3 \%$ & - & - & - & - & 1 & $0.2 \%$ \\
\hline Unspecified carnivores (NR) & 2 & - & 6 & - & 1 & - & - & - & 9 & - \\
\hline Total ungulates (NISP) & 176 & $94.1 \%$ & 302 & $94.4 \%$ & 1 & $25 \%$ & 135 & $94.4 \%$ & 613 & $93.9 \%$ \\
\hline P. antiquus & - & - & 6 & $1.9 \%$ & - & - & - & - & 6 & $0.9 \%$ \\
\hline S. hemitoechus & 4 & $2.1 \%$ & 2 & $0.6 \%$ & - & - & 1 & $0.7 \%$ & 7 & $1.1 \%$ \\
\hline E. f. germanicus & 61 & $32.6 \%$ & 86 & $26.9 \%$ & 1 & $25 \%$ & 38 & $26.8 \%$ & 186 & $28.5 \%$ \\
\hline E. hydruntinus & 17 & $9.1 \%$ & 24 & $7.5 \%$ & - & - & 12 & $8.5 \%$ & 53 & $8.1 \%$ \\
\hline Bison sp. & - & - & 1 & $0.3 \%$ & - & - & - & - & 1 & $0.2 \%$ \\
\hline B. primigenius & 22 & $11.8 \%$ & 20 & $6.3 \%$ & - & - & 11 & $7.7 \%$ & 53 & $8.1 \%$ \\
\hline C. caucasica & 1 & $0.5 \%$ & 8 & $2.5 \%$ & - & - & 4 & $2.8 \%$ & 13 & $2.0 \%$ \\
\hline C. elaphus & 52 & $27.8 \%$ & 116 & $36.3 \%$ & - & - & 48 & $33.8 \%$ & 216 & $33.1 \%$ \\
\hline D. dama & 3 & $1.6 \%$ & 7 & $2.2 \%$ & - & - & 1 & $0.7 \%$ & 11 & $1.7 \%$ \\
\hline R. tarandus & - & - & 2 & $0.6 \%$ & - & - & 1 & $0.7 \%$ & 3 & $0.5 \%$ \\
\hline C. capreolus & 4 & $2.1 \%$ & 5 & $1.6 \%$ & - & - & 2 & $1.4 \%$ & 11 & $1.7 \%$ \\
\hline S. scrofa & 12 & $6.4 \%$ & 25 & $7.8 \%$ & - & - & 16 & $11.3 \%$ & 53 & $8.1 \%$ \\
\hline Unspecified large ungulates (NR) & 36 & - & 58 & - & - & - & 29 & - & 123 & - \\
\hline Unspecified small ungulates (NR) & 646 & - & 1808 & - & - & - & 350 & - & 2804 & - \\
\hline Indeterminate large mammal (NR) & 25 & - & 41 & - & - & - & 27 & - & 93 & - \\
\hline $\begin{array}{c}\text { Total NISP } \\
\end{array}$ & 187 & $100 \%$ & 320 & $100 \%$ & 4 & $100 \%$ & 142 & $100 \%$ & 653 & $100 \%$ \\
\hline Total NR & & 96 & 2233 & & & 5 & & 48 & & \\
\hline
\end{tabular}

Tab. 5: Large Mammals composition in unit II levels of Ramandils Cave, by NISP (black) and NR (grey). 
296 Biological markers are noticed in the unit II levels, produced by various agents (tab. 6).

297

298

299

300

301

302

303

304

305

306

307

308

309

310

311

312

Human activities have the highest impact on more half remains, especially with burning processes increasing from the base, 52\% NR affected in S12, to the top, $79 \%$ NR affected in S10. Butchery activities are stable all along the levels with cut marks, on 13 to $20 \%$ of remains, and green fractures related to bone breakage, on 9 to $15 \%$ of remains, despite rare percussion marks, on less than 3\% of remains. At last few bone retouchers were found mainly on long bone fragment of cervids and unspecified small ungulates. Finally, the red deer remains are the most affected among all species by human impacts, while for the horse, butchery marks are scarcer.

Damage caused by carnivore activities are clearly more reduced, with less than $4 \%$ of remains affected by tooth marks and rare digested bones. These markers are observed on main species with close values, constant for the horse and with a low increase for the red deer in S11.

Other biological impacts are recorded. Rodent impact is insignificant in unit II levels with less than $1 \%$ of remains affected by scraping. Root marks increase from the base, with less than 5\% NR in S12, to the top, not exceeding $10.4 \% \mathrm{NR}$, inducing plant cover on the cave floor.

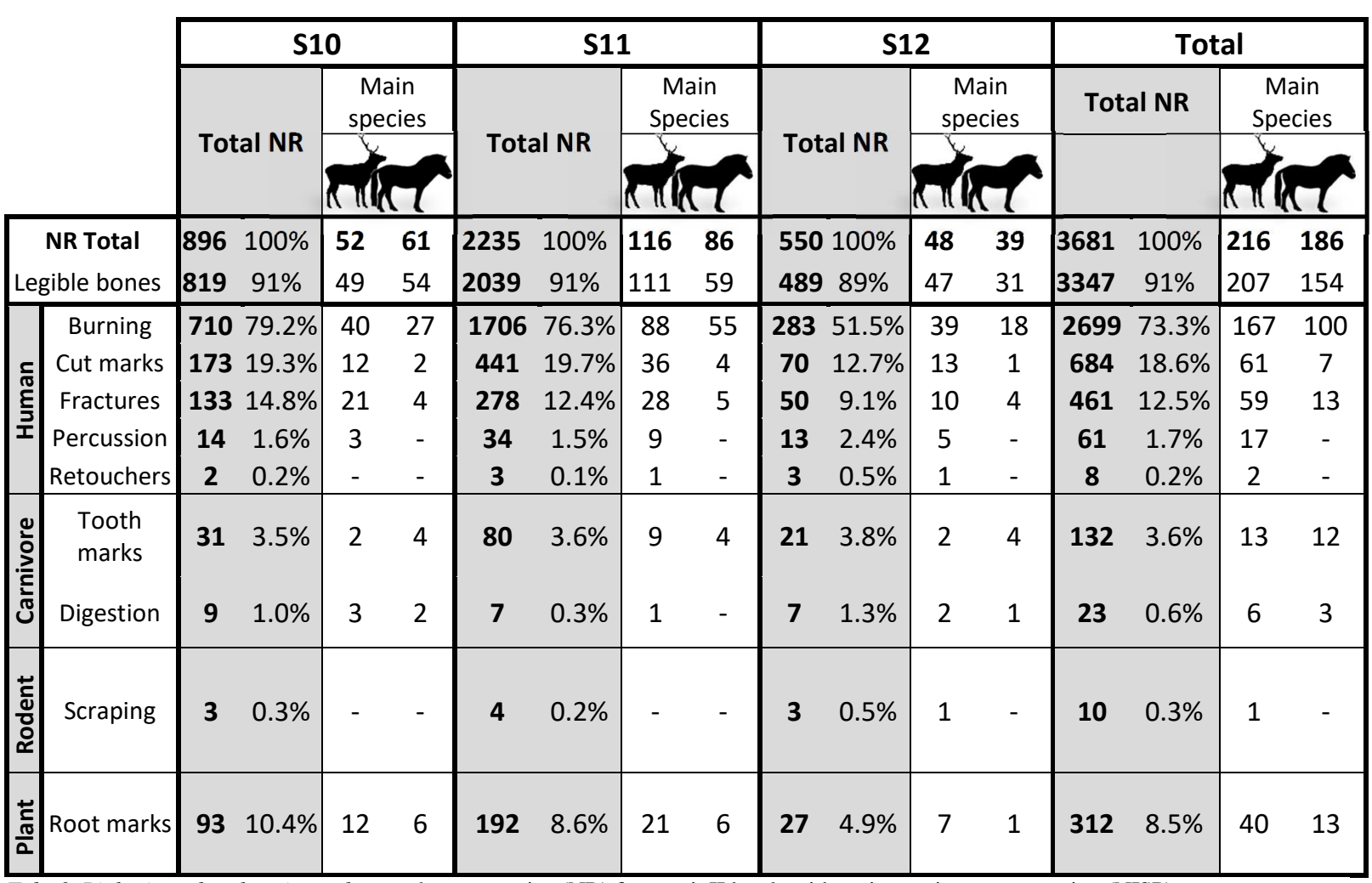


315 Direct evidence of carnivore occupation are noticed in unit II levels by a low percentage of 316 carnivore remains, 6\% NISP (tab. 5), with the cave hyena and the lynx relatively more 317 represented. Scarce marks on large mammal bones, less than $4 \%$ NISP in each level (tab. 6), 318 can be attributed to carnivore impact. Without considering unspecified ungulate remains 319 which have the highest values, traces are mainly recorded on main species, red deer and 320 horse. Most affected remains corresponding to burnt bones with butchery marks, such as green fractures, indicating carnivore scavenging during human abandonment periods of the cave. However, unburnt bones are affected (fig. 9), especially horse remains with whole long bones, which can be transported by large predators such as cave hyena. Further studies such as on the size of tooth marks will allow us to determine the specific agents affecting large mammal bones (Dominguez-Rodrigo \& Piqueras, 2003).

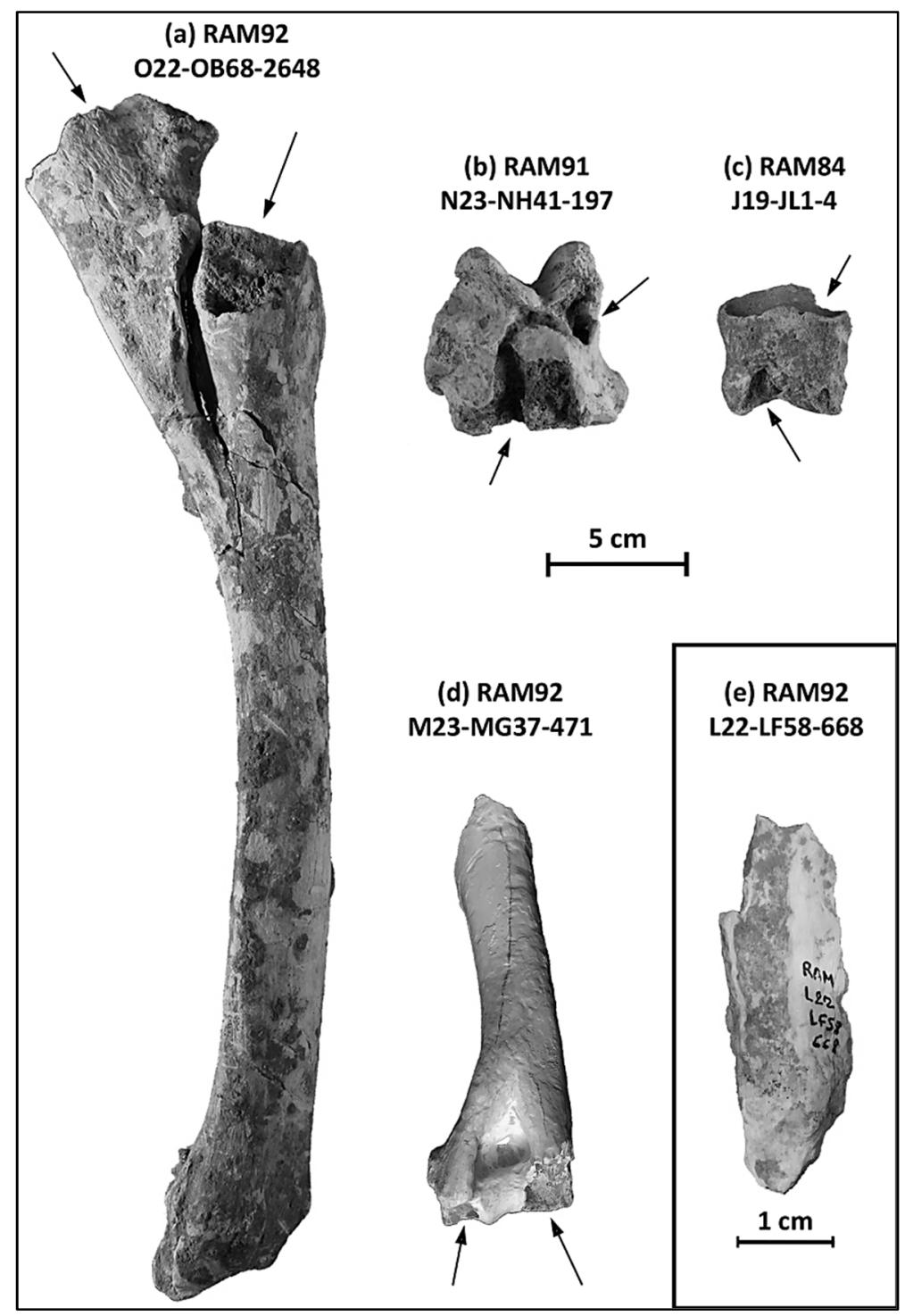

Fig. 9: Carnivore marks on unburnt ungulate remains: (a) epiphysis gnawing on a right radio-ulna of horse, $(b)$ puncturing marks on a left talus of horse, (c) epiphysis gnawing on a second phalanx of horse, (d) epiphysis gnawing on a right humerus of ibex, (e) digested metatarsal of red deer (photos L. Rusch and D. Dainat, Centre Européen de Recherches Préhistoriques, Tautavel). 
In unit II levels, 116 coprolites are coordinated, with some attributed to cave hyena in S12 333 (Lartigot-Campin \& Moné, 2017). In these levels anthropic impact evidence (lithic industry and burnt bones) are recorded, that confirm recurrent carnivore occupations during short abandonment periods of the site by human.

Two unit II levels are mainly constituted of coprolite beds, S12a and S13a, between occupation levels with human activity evidence (fig. 6). Archaeostratigraphical studies permit to observe coprolite concentrations in S12a, between the bands 21 to 22, especially in areas $\mathrm{M}, \mathrm{N}$ and $\mathrm{O}$ (fig. 10), with four carnivore remains. Indeed, two deciduous tooth of young cave hyena, one badger tibia and one sesamoid of unspecified bear are recorded. Likewise, one ungulate remain was found in S12a corresponding to a whole horse radio-ulna with gnawing marks (fig. 9a). Spatial distribution shows a coprolite concentration more or less circular in the squares N21 and O21 that suggests a latrine area (Bearder and Randall, 1978; Kruuk, 1972; Pineda et al., 2017), as well as in S13a, located in the square I21. Further study will confirm the presence or absence of latrines. However, it is interesting to see these coprolite beds at the limit of human occupations.

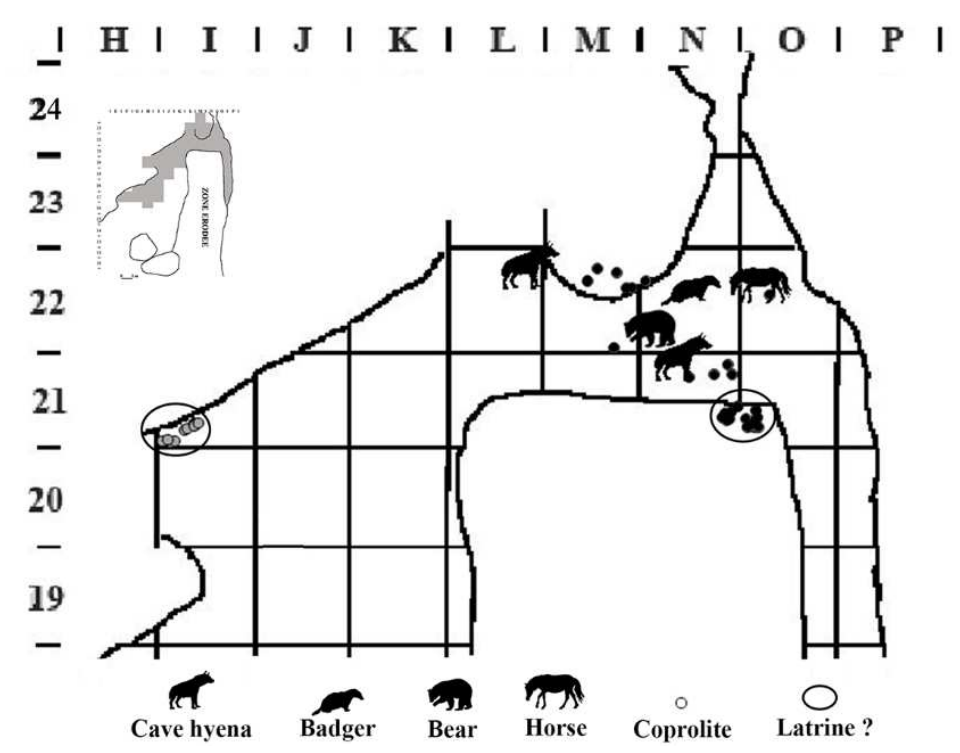

Fig. 10: Spatial distribution of levels S12a (black) and S13a (grey). Two areas with a coprolites concentration look like latrines. 
Fragments of indeterminate long bone $(2,469$ of total NR corresponding to $72 \%$ total NR without coprolites) are predominant in the distribution of anatomical elements (tab. 7) with 354 isolated teeth (385 of total NR as $10 \%$ of Total NR without coprolites) attesting to high 355 taphonomic impact. However, fragile elements are recorded in the sequence as cranium 356 (76 total NR), vertebrae (46 total NR), and ribs (36 total NR), adding carnivore coprolites 357 (135 total NR) distributed in the three levels and in S12a.

Main species are less than 100 total NISP, except for the red deer in S11 (116 total NISP) with prevalence of isolated teeth and long bones, such as metapodials, in each level (tab. 7). Almost all skeletal elements of red deer are recorded in S11 and S12, whereas axial elements and bones of hind quarter are missing in S10. For the horse, skeletal distribution seems reversed compared to red deer remains with almost all skeletal elements in S10 and S11, whereas hind leg bones are lacking in S12. For secondary species partial skeletal distribution is recorded in each level with mainly teeth and long bones.

\begin{tabular}{|c|c|c|c|c|c|c|c|c|c|c|c|c|c|}
\hline & \multicolumn{3}{|c|}{ S10 } & \multicolumn{3}{|c|}{ S11 } & S12a & \multicolumn{3}{|c|}{ S12 } & \multicolumn{3}{|c|}{ Total } \\
\hline & $\begin{array}{c}\text { Total } \\
\text { NR }\end{array}$ & \multicolumn{2}{|c|}{ Main species } & $\begin{array}{c}\text { Total } \\
\text { NR }\end{array}$ & \multicolumn{2}{|c|}{ Main species } & $\begin{array}{c}\text { Total } \\
\text { NR }\end{array}$ & $\begin{array}{c}\text { Total } \\
\text { NR }\end{array}$ & \multicolumn{2}{|c|}{ Main species } & $\begin{array}{c}\text { Total } \\
\text { NR }\end{array}$ & \multicolumn{2}{|c|}{ Main species } \\
\hline Antler/horn & 13 & 9 & - & 11 & 7 & - & - & 5 & 1 & - & 29 & 17 & 0 \\
\hline Cranium & 16 & 1 & 2 & 43 & 5 & 2 & - & 17 & 1 & 1 & 76 & 7 & 5 \\
\hline Maxilla & 6 & - & - & 3 & - & - & - & 3 & - & - & 12 & 0 & 0 \\
\hline Mandible & 4 & - & - & 9 & 1 & 2 & - & 7 & 3 & - & 20 & 4 & 2 \\
\hline Tooth & 124 & 13 & 37 & 170 & 31 & 51 & 2 & 89 & 12 & 24 & 385 & 56 & 112 \\
\hline Vertebra & 11 & - & 2 & 19 & 2 & 3 & - & 16 & 2 & 1 & 46 & 4 & 6 \\
\hline Rib & 4 & - & 2 & 22 & 3 & 5 & - & 10 & - & 1 & 36 & 3 & 8 \\
\hline Scapula & 1 & 1 & - & 2 & - & 1 & - & 2 & - & - & 5 & 1 & 1 \\
\hline Humerus & 2 & 1 & - & 8 & 5 & - & - & 4 & 1 & 2 & 14 & 7 & 2 \\
\hline Radio-ulna & 9 & 7 & 1 & 12 & 7 & 2 & 1 & 3 & 1 & 1 & 25 & 15 & 5 \\
\hline Carpus & - & - & - & 2 & - & 1 & - & 1 & 1 & - & 3 & 1 & 1 \\
\hline Metacarpus & 11 & 7 & 4 & 24 & 13 & 6 & - & 6 & 5 & 1 & 41 & 24 & 11 \\
\hline Pelvis & 1 & - & - & 6 & 1 & 4 & - & 4 & - & 3 & 11 & 1 & 7 \\
\hline Femur & 1 & - & - & 9 & 6 & - & - & 5 & 2 & 2 & 15 & 8 & 2 \\
\hline Tibia & 2 & - & 2 & 4 & 3 & - & 1 & 6 & 4 & - & 13 & 7 & 2 \\
\hline Tarsus & 2 & - & 1 & 5 & 1 & 1 & - & 3 & 2 & - & 10 & 3 & 2 \\
\hline Metatarsus & 19 & 8 & 5 & 34 & 20 & 5 & - & 11 & 10 & - & 64 & 38 & 10 \\
\hline Metapodial & 4 & & 1 & 3 & 1 & - & - & 2 & 1 & - & 9 & 3 & 1 \\
\hline Sesamoid & 2 & 1 & - & 8 & 3 & 1 & 1 & 2 & 1 & - & 13 & 5 & 1 \\
\hline Phalanx & 17 & 4 & 4 & 21 & 7 & 2 & - & 6 & 1 & 2 & 44 & 12 & 8 \\
\hline Long bone & 580 & - & - & 1596 & - & - & - & 293 & - & - & 2469 & - & - \\
\hline Cancellous bone & 62 & - & - & 208 & - & - & - & 48 & - & - & 318 & - & - \\
\hline Flat bone & 5 & - & - & 14 & - & - & - & 5 & - & - & 24 & - & - \\
\hline Coprolite & 7 & - & - & 39 & - & - & 27 & 43 & - & - & 116 & - & - \\
\hline Total NR & 903 & \multirow[b]{2}{*}{52} & \multirow[b]{2}{*}{61} & 2272 & \multirow[b]{2}{*}{116} & \multirow[b]{2}{*}{86} & 32 & 591 & \multirow[b]{2}{*}{48} & \multirow[b]{2}{*}{38} & 3798 & \multirow[b]{2}{*}{216} & \multirow[b]{2}{*}{186} \\
\hline $\begin{array}{c}\text { Total NR } \\
\text { without coprolites }\end{array}$ & 896 & & & 2233 & & & 5 & 548 & & & 3682 & & \\
\hline
\end{tabular}


In unit II levels, $99 \%$ of long bones (without considering phalanges) are broken. The diaphysis lengths are generally less than $50 \mathrm{~mm}$ and the diaphysis circumferences are either less than half of their original dimensions, or complete in rarer cases (as for the few whole bones).

For main species, long bones are not represented with the same size distribution (fig. 11). Red deer bones are highly fragmented with most remains measuring less than $50 \mathrm{~mm}$ in the three levels (fig. 11), corresponding to less than $1 / 4$ diaphysis lengths. One complete epiphysis was discovered in S11, an unfused proximal extremity of the right tibia, and no whole elements are recorded in unit II levels. This profile can be explained by the prevalence of anthropic impacts on red deer remains (tab. 6).

Throughout the sequence, the horse is the only large mammal with complete long bones, excavated in unit II levels and corresponding to metapodials in S10 and S11 (fig. 11) with a radio-ulna in S12a (fig. 9a). Furthermore, two complete metatarsal epiphyses, with their diaphysis portion, have been reassembled in S10 and two complete metacarpal epiphyses with their diaphysis portion have likewise been reassembled in S11. These remains are counted as partial element in NISP but form two actual whole metapodials in addition to the other complete long bones. Considering this low fragmentation with unburnt whole bones, human activities seem less affect horse remains, supporting by carnivore tooth marks on unburnt elements (fig. 9a, b, c).

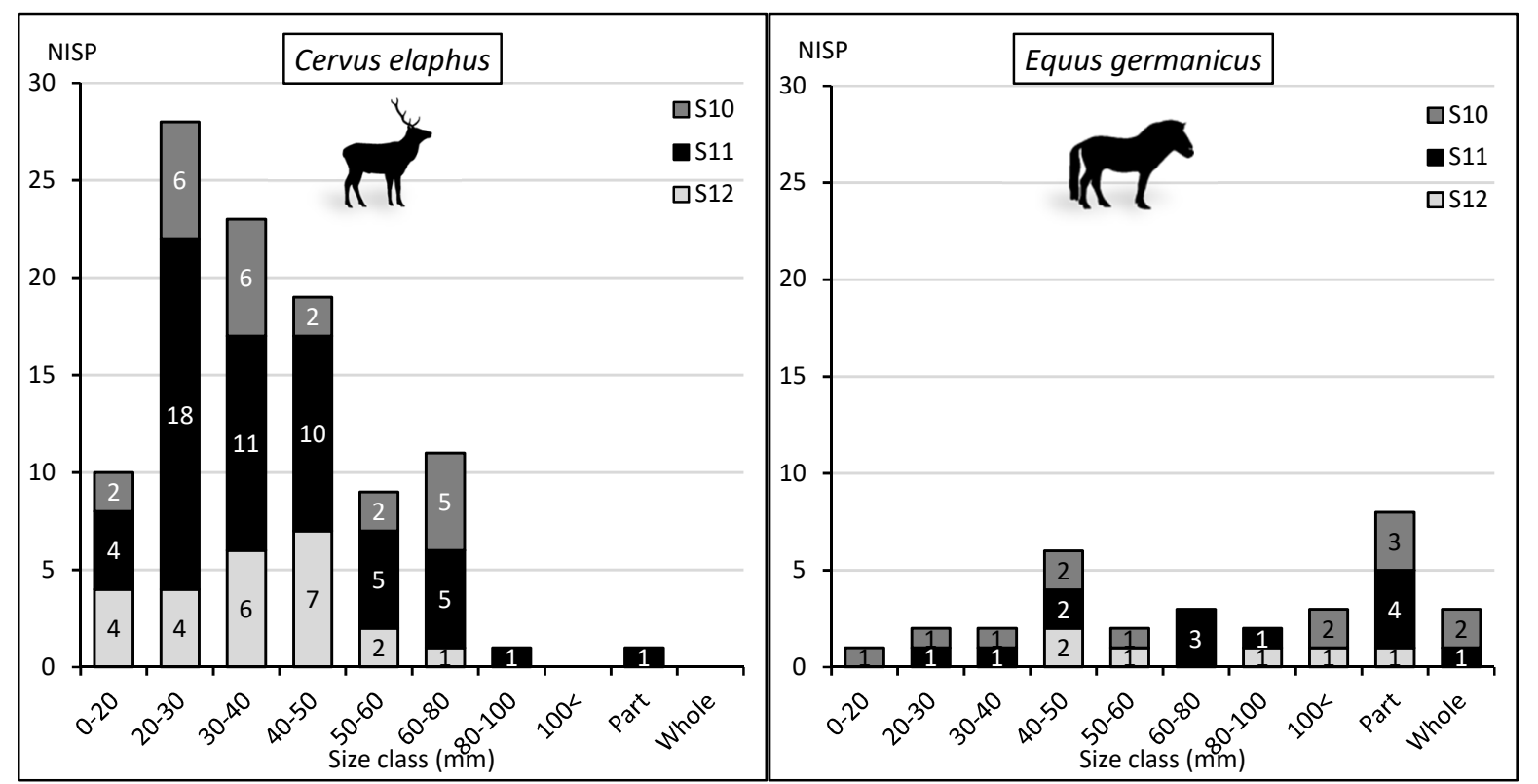

Fig. 11: Fragmentation indexes of long bones. Comparison of NISP between red deer and horse by Size class (mm), partial elements with a complete epiphysis (Part), and complete long bones (Whole) 
Human impact (tab. 6) is mainly attested with various burning processes affecting faunal remains mostly for red deer (tab. 8). Degree 1 (brown colour), is the most represented bone modification (47 to $61 \%$ of affected NR) decreasing from the base to the top. This first step applies to heated bones at low temperature less than $300^{\circ} \mathrm{C}$ (Lebon, 2009). Degree 4 (grey colour) is well represented (16 to $27 \%$ of affected NR), increasing between levels. This burning step, for temperatures between 400 and $550^{\circ} \mathrm{C}$, and partly explain the high fragmentation of faunal material. In contrast, degree 3 (black colour) and degree 6 (white colour) with less than $5 \%$ of affected NR are the least represented. Double colouration is observed on 5 to $8 \%$ of affected NR.

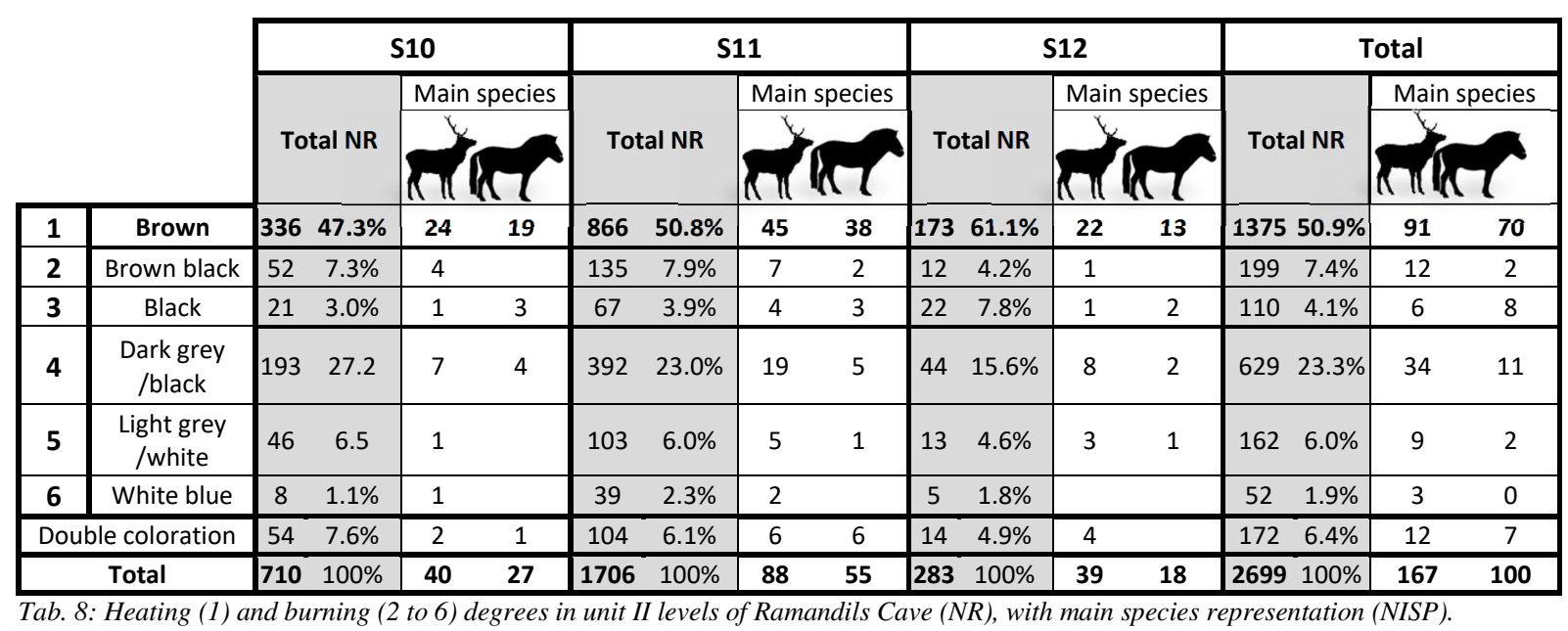

Heating or burning processes are observed on each skeletal element in unit II levels, mainly on teeth and indeterminate long bones. For red deer from the three main levels (fig. 12), heating is likewise generally localised on teeth and long bones, especially on metapodials and radio-ulna, followed by cranium and antler fragments. These distributions support the hypothesis of bone marrow exploitation with long bone preparation by heating process.

Bones bearing cut marks (13 to $19 \% \mathrm{NR}$ ), or green fractures (9 to $15 \% \mathrm{NR}$ ), with higher percentages in S11 and S10 (tab. 6) are mainly concentrated on unspecified small ungulates as well as on red deer. These anthropic modifications present similar distribution on red deer skeletal (fig. 13), mostly located on long bones, especially on metapodials and radio ulna, likewise for heated processes (fig. 12). 


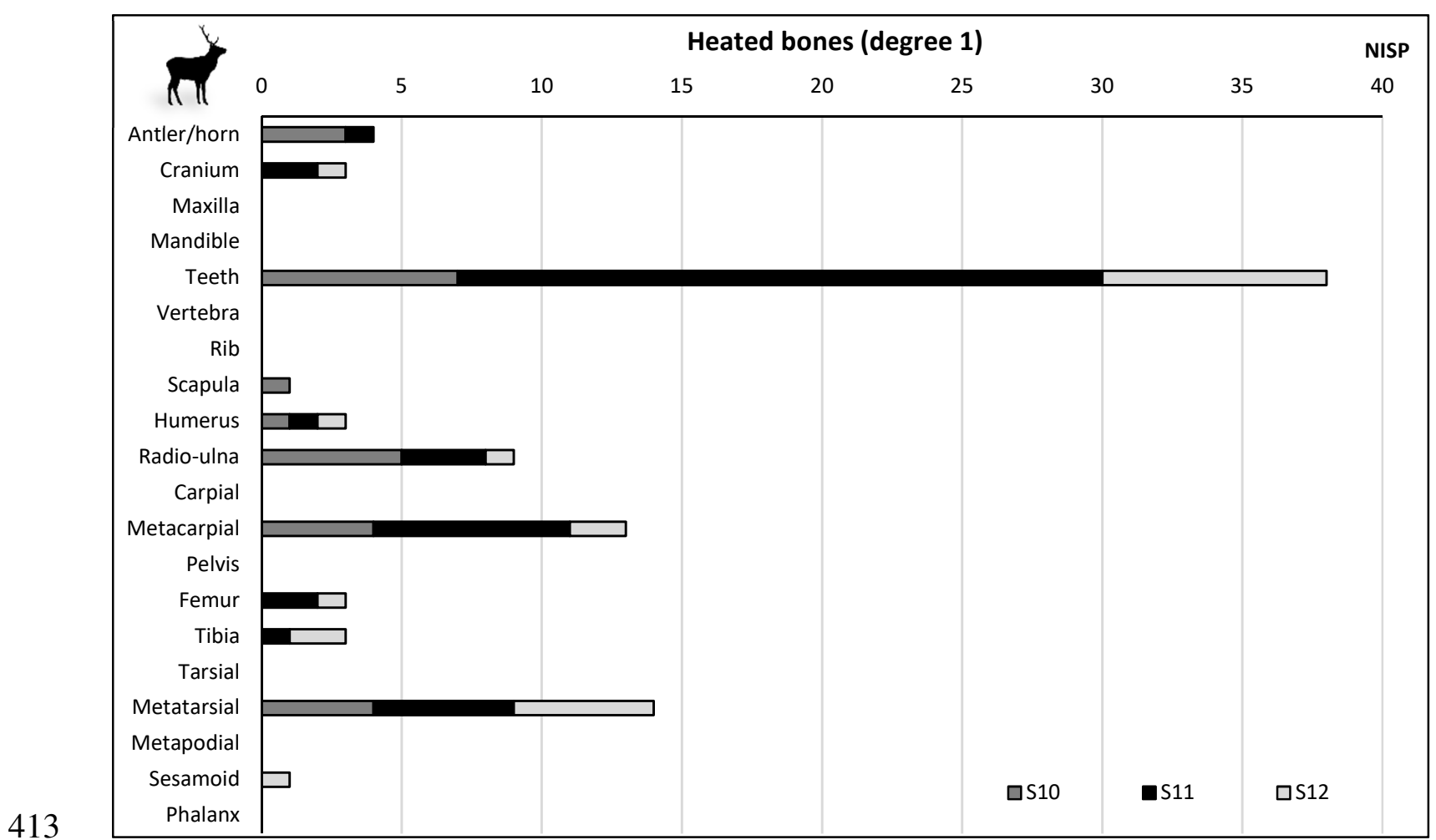

414 Fig. 12: Skeletal distribution (NISP) of heated bones (degree 1) for red deer.

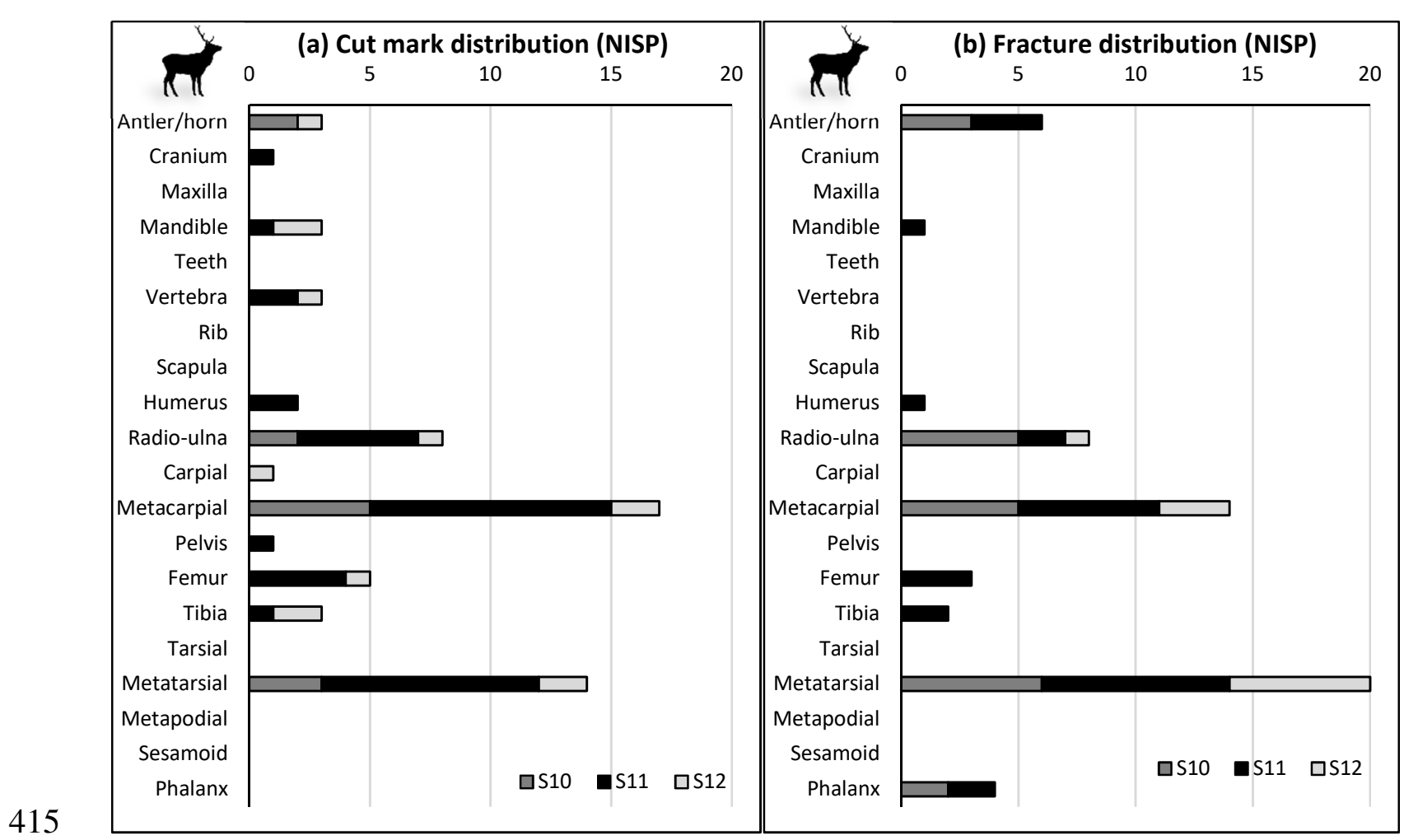

416 Fig. 13 (a) Cut mark and (b) green fracture distribution on red deer skeletal (NISP) in unit II levels of Ramandils Cave 
Several butchery step were noticed, generally affecting burnt remains, based on morphology, localization and distribution of traces over the bone surface (Binford 1981).

420 Cut marks on burnt cranium of red deer in S11 (fig. 13a) and on one horse phalange in S10 421 could indicate skinning process, as well as for wild boar, with a cranium and phalanges 422 likewise affected in these same levels. However, unlike the wild boar and fallow deer, third 423 phalanges are missing for all ungulates, which may support the hypothesis of an out-site 424 skinning process on main species, or show a differential treatment such as burning process.

425

426

427 Incisions on articular parts are observed on carpus and mandible, thoracic vertebrae and long bones extremities (humerus, femur and metapodials) for the red deer in S11 and S12 (fig. 13a), interpreted as disassembling step, likewise recorded for aurochs in S11. Traces are recorded in the three levels, on mandibles, ribs, or diaphysis of meat-rich long bones for main species (fig. 13a), showing defleshing processes, likewise for secondary species, essentially aurochs (in S10 and S11) and for wild boar (in the three levels).

Scraping marks are noticed on diaphysis of red deer metapodials (fig. 13a). These meatpoor elements are affected by long fine parallel striation to the longitudinal bone axe (fig. 14a) or short and close parallel marks perpendicular to the bone shaft (fig. 14c) caused by the removal of periosteum. This cleaning process allows to facilitate bone breakage. Moreover, green fracture on mandible and long bones, mainly on red deer metapodials (fig. 13a, fig. 14a), represents the bone marrow removing step, abundant inside these anatomical parts. Some of these remains show percussion marks related to this process.

Carnivores are also affected by butchery marks noticed on heated remains. Incisions are noticed on a wolf occipital in S12 (fig. 14d) and a cave bear phalange in S11 (fig. 14f), which can be explained by a disassembling process for the first and a skinning step for the second. Remains of brown bear, Ursus arctos, are likewise heated in unit II, with one phalange in S12 and one fibula bearing cut traces could interpreted as skinning marks, in S13 (fig. 14e).

At last, technological applications of bones are identified in the three levels, corresponding to scarce bone retouchers (tab. 6), mainly on heated long bones of cervids (fig. 14b). 


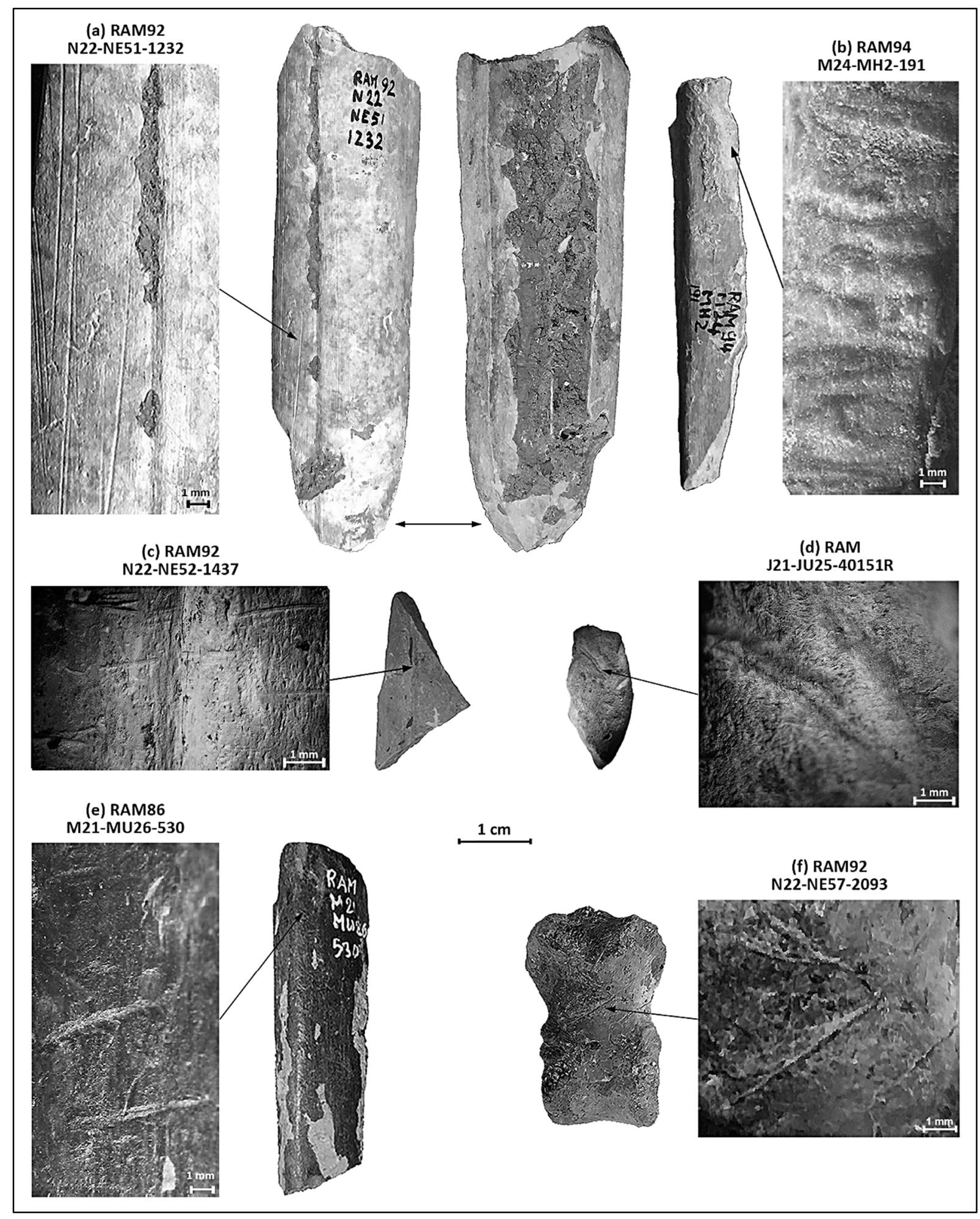

Fig. 14: Anthropic marks on large mammal remains: (a) scraping marks and green fracture on an unburnt metacarpal of red deer, (b) bone retoucher on a brown heated metatarsal of roe deer, (c) scraping marks on blue burnt metacarpal of red deer, (d) cut marks on an heated brown temporal of wolf, (e) cut marks on brown heated fibula of brown bear, $(f)$ cut marks on brown heated phalanx of cave bear (photo by L. Rusch). 
A low MNI is defined for each species (tab. 9) which not exceeds seven individuals, with red deer in S11. Closer count is recorded in S11 between main species, red deer (7 individuals) and horse (6 individuals), and secondary species are well represented in this level by European wild ass ( 5 individuals), aurochs ( 5 individuals) and wild boar ( 4 individuals). Furthermore, fallow deer, with 5 individuals, counts higher MNI than in other levels. In S10 equids are greater represented, by horse and European wild ass, with 6 individuals for each,

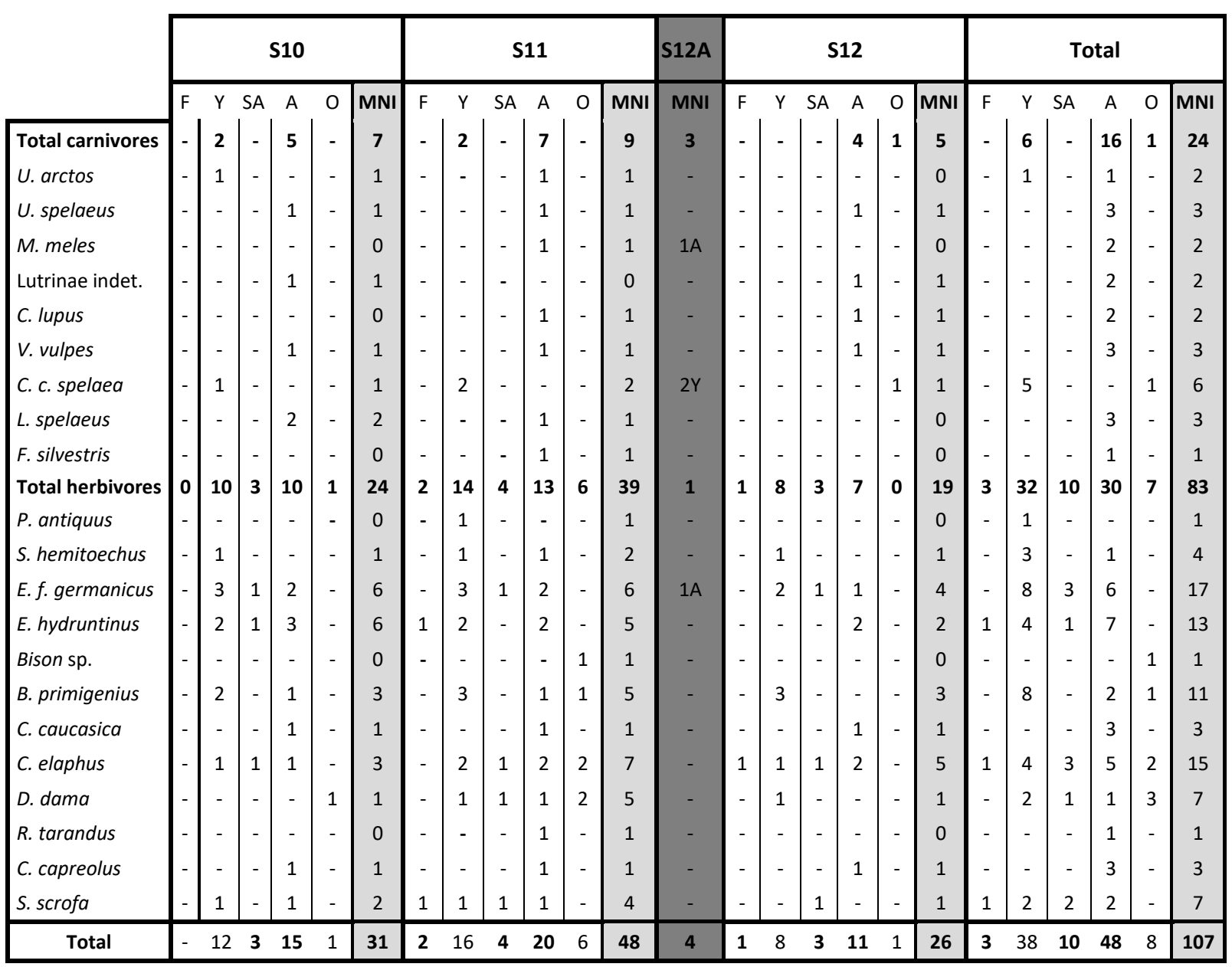

compared to red deer (3 individuals) and aurochs (3 individuals).

Tab. 9: Age groups of large mammals (MNI by combination) in unit II levels of Ramandils Cave: (F) foetus, (Y) young, (SA) sub-adult, (A) adult, and $(O)$ old individuals.

462 Carnivores are scarcer, not exceeding 2 individuals by species, and relatively more 463 represented by cave hyena, with 6 individuals of total MNI. Young individuals are only 464 recorded for brown bear in S11 and cave hyena in S11 and S12a (tab. 9), and one senile cave hyena is noticed in $\mathrm{S} 12$. 
For ungulates, the mortality patterns indicate that all age groups are present in unit II, and particularly among dominant species. Adults are the most abundant, closely followed by young individuals (infants or juveniles) and to a lesser extent by sub-adults. This last age group corresponds to animals which have nearly reached their maximum size, meaning that hunting a sub-adult prey could have involved the same diet resources as an adult animal. One senile fallow deer is recorded in S10 while six senile prey are represented in S11 corresponding to one bison, one aurochs, two red deer and two fallow deer. We determined three foetus teeth in unit II, for wild boar and European wild ass in S11 and for red deer in S12, meaning that female adult animals were targeted, however no criteria on bones remains allow us to distinguish them.

Ungulates were generally slaughtered several times during the year (fig. 15), with spring, autumn and winter always recorded in the three levels. Prey selection followed a seasonal pattern for cervids, systematically occurring during autumn, in the three levels and during spring in S12. In the same way, in S11 and S10, horse was generally hunted between spring and summer, European wild ass rather during winter, and wild boar during summer, while in $\mathrm{S} 12$, seasonal recording is not represented for these species. Moreover, aurochs were slaughtered during various periods, hunted during spring in S11 whereas this bovid is represented during autumn in S10 and S12, as well as during winter in S12.
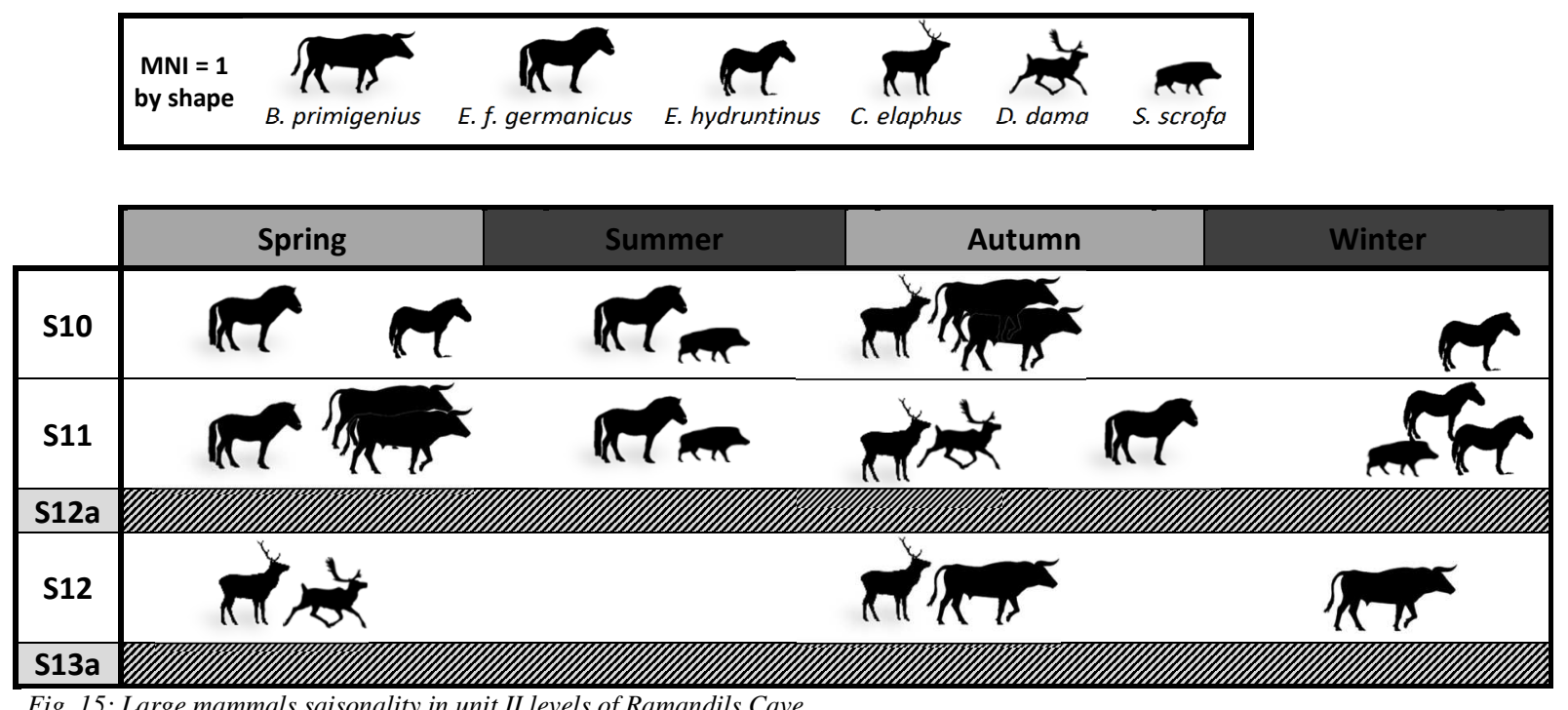

Fig. 15: Large mammals saisonality in unit II levels of Ramandils Cave 


\section{Discussion}

The results obtained in this study contribute relevant details to knowledge of Neanderthal and carnivore occupations in unit II of Ramandils Cave (tab. 10), and therefore on Mediterranean coast during the Upper Pleistocene. The three more abundant unit II levels record several occupation periods occurred, the densest of which is undoubtedly observed in level S11.

\subsection{Occupations in Unit II Levels}

For the material accounted, S8, S9, S13 and S14 are the lower levels of unit II, except for coprolites levels S12a and S13a. Further studies will refine these four occupation levels for allow us to characterise unit III and unit I limits with unit II levels.

\section{- $\quad$ S13a}

S13a level constitute a coprolite deposit in a concentrated area more or less circular. This distribution could be interpreted as a latrine deposit, usually attributed to cave hyena layer (Bearder and Randall, 1978; Crezzini et al., 2015; Fernandez Rodriguez et al., 1995; Fosse, 1997; Fourvel, 2012; Kruuk, 1972; Pineda et al., 2017), indicating at least one carnivore occupation during long periods of human abandonment. However, further studies will allow us to characterise this level.

Anthropic impact is well attested in S12 level, especially with lithic industry and burnt faunal bones. Red deer and horse remains are prevalent for large mammals, in NISP and MNI. Secondary species are recorded mainly corresponding to aurochs, European wild ass, and wild boar, with lower values of NISP and MNI. Several carnivore species were identified, for less than $6 \%$ NISP, relatively represented by wolf and cave hyena, with a low MNI.

Almost all skeletal parts are recorded for the red deer, explained by a whole carcasses transport, but hind limb bones were not found for the horse, which could be explained by partial carcass transport likewise for secondary species. However, the lack of third phalanges for all species may indicate a previous skinning step out-site or differentiated impacts for this anatomical elements such as with burning processes. Several butchery steps are noticed, mainly on long bones of red deer. Firstly, disassembling and defleshing marks indicate a meat exploitation, likewise noticed for one wolf remain for the first process. Secondly, scraping marks, resulting of bone cleaning processes, mainly on metapodials, with green fractures, and some percussion marks induce a bone marrow consumption, supported by the high material fragmentation.

Then, high values of heated to burnt bones are highlighted in this level, without any hearths recorded in the sequence. These structures may be located in non-excavated area or might not be preserved, especially in the eroded area on the front of the cave, caused by the active natural spring. Heating and burning in the set may suggest various processes and could partly explain the high material fragmentation. Scarce double colouration on same bone surface indicates differential heat exposure and could suggest possible roasting of the meat, prior to 
524 defleshing (Rosell et al., 2012). However, the high bone fragmentation can affect evidence of 525 this meat preparation process, especially for diaphysis fragments. Low calcination can 526 indicate a bone preparation to facilitate their fractures (Cáceres et al., 2002) or preparing bone 527 marrow for removal (Oliver, 1993; Speth et al., 2012), while high calcination could show 528 possible cleaning activities. The low representation of cancellous bones (articular portions, 529 limb extremities or axial skeleton) and the small number of percussion fragments does not 530 exclude the hypothesis of bone grease exploitation or the use of bones as fuel (Daujeard, 531 2008; Lebon, 2008; Morin, 2007, 2010). Further studies would allow us to explain these 532 proportions.

533 Young and adult ungulates, with close MNI, seem to be slaughtered without any age 534 selection. Despite low MNI of large mammals, studies show occupations occurred during 535 almost each seasonal period of the year. This faunal studies could indicate specialised 536 seasonal hunting, especially focus on cervids (red deer and fallow deer) during spring and on 537 aurochs during winter, with a mixed period for red deer and aurochs during autumn, other 538 species such as horse not estimating in months.

539 Moreover, low carnivore occurrence is noticed within S12 level. Few carnivore remains 540 are identified, especially wolf and cave hyena. Scarce tooth and digestion marks, mainly 541 affecting heated and fractured ungulate bones, and coprolites induce scavenging during short 542 human abandonment of the cave.

$543-\mathrm{S} 12 \mathrm{a}$

544 Another coprolite layer, noted S12a, was described during this study, implying recurrent 545 carnivore occupation of Ramandils cave in unit II. In addition to a richer coprolite bed with a 546 concentrated area more or less circular, S12a records few carnivore remains, especially two 547 young cave hyena ( $2 \mathrm{MNI})$, as well as one gnawed long bone of horse, the only one ungulate 548 remains. These results could be interpreted as a latrine deposit and explained by the use of the 549 cave as a den by the cave hyena, usually generating this type of distribution (Kruuk, 1972; 550 Bearder \& Randall, 1978; Pineda et al., 2017). However, further studies will allow us to 551 characterise this layer. 
S11 is the richest unit II level with anthropic activities such as lithic industry and butchery processes. The same main species are recorded than in S12 with the prevalence of red deer and similar distribution is noticed for secondary species. Carnivores are more varied for less than $6 \%$ NISP, relatively represented by hyena and canids with a low MNI.

Almost all skeletal parts are recorded for the main species, explained by a whole carcasses transport, whereas, as in S12, a partial transport is interpreted for secondary species. However, the lack of third phalanges for ungulates, except for wild boar and fallow deer, may still indicate a previous skinning step out-site or differentiated impacts for this anatomical elements such as with burning processes. The same butchery steps are noticed, mainly on long bones of red deer, with the addition of skinning marks for red deer and wild boar, likewise on a cave beer phalange. High values of heating and burning processes have the same interpretation as for S12.

Young and adult ungulates, with close MNI, seem to be slaughtered without any age selection. Despite low MNI of large mammals, seasonality studies could indicate longer or more frequent occupations than in S12. Specialised seasonal hunting seems focus on cervids during autumn and on bovids during spring, with a regular slaughtering of suids and equids (horse and European wild ass) for almost each seasonal periods of the year. European wild ass seems rather hunted during winter, as well as suids, likewise killed during summer.

Moreover, low carnivore occurrence is still noticed within S11 level with the same scavenging marks during short human abandonment of the cave. However, considering the preservations of few whole long bones and tooth marks on unburnt remains, not affected by human activities, carnivore may have transported some of their own prey into the cave ().

$-\quad$ S10

No coprolites level is noticed between S11 and S10 levels as opposed between S13 and S12 with S13a level and between S12 and S11 with S12a level. In S10, recording human occupation evidence, horse is prevalent compared to red deer with the same faunal spectrum and close values for secondary species as in S12 and S11. Carnivores are fewer diversified, represented in lesser extend by cave hyena and lynx.

Almost all skeletal parts are recorded for the horse, explained by a whole carcasses transport, but axial elements and bones of hind quarter were not found for the red deer, which could be explained by partial carcass transport likewise for secondary species. However, the lack of third phalanges for ungulates, except for wild boar and fallow deer, may indicate a previous skinning step out-site or differentiated impacts for this anatomical elements such as with burning processes. Several butchery marks are noticed, mainly on long bones of red deer. Skinning step is highlighted for horse and wild boar. Disassembling is not recorded in S10 but other butchery steps are the same as in S11 and S12, likewise for heating and burning processes with the same interpretations as for other levels. 
Young and adult ungulates, with close MNI, seem to be slaughtered without any age selection as seen in other levels. Seasonality studies show occupations occurred each seasonal period of the year. Despite low MNI of large mammals, this faunal studies could indicate specialised seasonal hunting, similar to the previous levels, for Cervids and bovids which seem rather killed during autumn, as seen in S12, whereas equids were slaughtered during almost each season, with a focus on European wild ass during winter, as notice in S11. Therefore, Suids seem killed during summer likewise in S11 level.

Carnivore occurrence is still noticed within S10 level with the same scavenging marks during short human abandonment of the cave. However, considering the preservations of few whole long bones and tooth marks on scarce unburnt remains, not affected by human activities, carnivore may have transported some of their own prey into the cave.

\begin{tabular}{|c|c|c|c|c|c|c|c|c|c|c|c|}
\hline & \multicolumn{7}{|c|}{ Human activities } & \multicolumn{4}{|c|}{ Carnivores activities } \\
\hline & Hunted prey & Transport & Butchery steps & Fire & Exploitation & Saisonality & $\begin{array}{c}\text { Bone } \\
\text { industry }\end{array}$ & $\begin{array}{c}\text { Main } \\
\text { species }\end{array}$ & Activities & Coprolites & Occupation \\
\hline \multirow[b]{2}{*}{ S10 } & $\begin{array}{l}\text { - Main: } \\
\text { - Horse } \\
\text { - Red deer } \\
\end{array}$ & Whole & \multirow{2}{*}{$\begin{array}{l}\text { - Skinning } \\
\text { - Defleshing } \\
\text { - Breakage }\end{array}$} & \multirow{2}{*}{$\begin{array}{c}\text { Heating } \\
+ \\
\text { Burning }\end{array}$} & \multirow{2}{*}{$\begin{array}{c}\text { Meat } \\
+ \\
\text { Bone marrow }\end{array}$} & \multirow{2}{*}{$\begin{array}{l}\text { Seasonal } \\
\text { selective } \\
\text { slaughters }\end{array}$} & \multirow{2}{*}{$\begin{array}{c}\text { Rare } \\
\text { retouchers }\end{array}$} & \multirow{2}{*}{$\begin{array}{c}\text { Cave hyena } \\
\text { (young) } \\
+ \\
\text { Lynx (adult) }\end{array}$} & \multirow{2}{*}{$\begin{array}{c}\text { Scavenging } \\
+ \\
\text { Few gnawing } \\
\text { remains no } \\
\text { affected by } \\
\text { human }\end{array}$} & \multirow[b]{2}{*}{ yes } & \multirow[b]{2}{*}{ occasional } \\
\hline & $\begin{array}{l}\quad \text { Secondary: } \\
\text { - Aurochs } \\
\text { - European wild ass } \\
\text { - wild board } \\
\end{array}$ & \begin{tabular}{|c|} 
Partial \\
Mainly skull \\
and \\
limb ends \\
\end{tabular} & & & & & & & & & \\
\hline \multirow[b]{2}{*}{ S11 } & \begin{tabular}{l}
\multicolumn{1}{c}{ Main: } \\
- Red deer \\
- Horse
\end{tabular} & Whole & $\begin{array}{l}\text { Disassembling } \\
\text { - Defleshing } \\
\text { - Breakage } \\
\end{array}$ & \multirow[b]{2}{*}{$\begin{array}{c}\text { Heating } \\
+ \\
\text { Burning }\end{array}$} & \multirow[b]{2}{*}{$\begin{array}{c}\text { Meat } \\
+ \\
\text { Bone marrow }\end{array}$} & \multirow[b]{2}{*}{$\begin{array}{l}\text { Seasonal } \\
\text { selective } \\
\text { slaughters }\end{array}$} & \multirow[b]{2}{*}{$\begin{array}{c}\text { Rare } \\
\text { retouchers }\end{array}$} & \multirow{2}{*}{$\begin{array}{c}\text { Cave hyena } \\
\text { (young) } \\
+ \\
\text { Fox (adult) }\end{array}$} & \multirow{2}{*}{$\begin{array}{c}\text { Scarce: } \\
\text { Scavenging } \\
+ \\
\text { Few gnawing } \\
\text { remains no } \\
\text { affected by } \\
\text { human }\end{array}$} & \multirow[b]{2}{*}{ yes } & \multirow[b]{2}{*}{ occasional } \\
\hline & $\begin{array}{l}\quad \text { Secondary: } \\
\text { - Wild board } \\
\text { - European wild ass } \\
\text { - Aurochs }\end{array}$ & \begin{tabular}{|c|}
$\begin{array}{c}\text { Partial } \\
\text { Selection } \\
\text { of pieces } \\
\text { according to } \\
\text { taxa }\end{array}$ \\
\end{tabular} & $\begin{array}{l}\text { - Skinning } \\
\text { - Disassembling } \\
\text { - Defleshing } \\
\text { - Breakage } \\
\end{array}$ & & & & & & & & \\
\hline S12a & & & & & & & & $\begin{array}{l}\text { Cave hyena } \\
\text { (Young) }\end{array}$ & \begin{tabular}{|c|}
$\begin{array}{c}\text { Gnawing on } \\
\text { one whole } \\
\text { radio-ulna } \\
\text { of horse }\end{array}$ \\
\end{tabular} & $\begin{array}{l}\text { Latrine } \\
\text { level? }\end{array}$ & Den? \\
\hline \multirow[b]{2}{*}{ S12 } & \begin{tabular}{l}
\multicolumn{1}{c}{ Main: } \\
- Red deer \\
- Horse \\
\end{tabular} & Whole & $\begin{array}{l}\text { Disassembling } \\
\text { - Defleshing } \\
\text { - Breakage } \\
\end{array}$ & \multirow{2}{*}{$\begin{array}{c}\text { Heating } \\
+ \\
\text { Burning }\end{array}$} & \multirow{2}{*}{$\begin{array}{c}\text { Meat } \\
+ \\
\text { Bone marrow }\end{array}$} & \multirow{2}{*}{$\begin{array}{l}\text { Seasonal } \\
\text { selective } \\
\text { slaughters }\end{array}$} & \multirow{2}{*}{$\begin{array}{c}\text { Rare } \\
\text { retouchers }\end{array}$} & \multirow{2}{*}{$\begin{array}{c}\text { Cave hyena } \\
\text { (young / old) } \\
+ \\
\text { Wolf (adult) }\end{array}$} & \multirow[b]{2}{*}{ Scavenging } & \multirow[b]{2}{*}{ Yes } & \multirow[b]{2}{*}{ occasional } \\
\hline & $\begin{array}{l}\quad \text { Secondary: } \\
\text { - Wild board } \\
\text { - European wild ass } \\
\text { - Aurochs }\end{array}$ & $\begin{array}{c}\text { Partial } \\
\text { Mainly skull } \\
\text { and } \\
\text { limb ends }\end{array}$ & $\begin{array}{l}\text { - Defleshing } \\
\text { - Breakage }\end{array}$ & & & & & & & & \\
\hline S13a & & & & & & & & None & & $\begin{array}{l}\text { Latrine } \\
\text { level? }\end{array}$ & occasional \\
\hline
\end{tabular}

In S10 S11, S12 levels, the material accumulation is mainly due to human input representing various activities during several occupations periods recorded within unit II but also in the whole sedimentary filling of the cave.

Even if the archeological interpretation from paleoenvironments to settlement pattern 606 depends on the temporal resolution of the data (Carbonell et al, 2012), this first and 607 preliminary multidisciplinary approach allow us to propose and discuss various hypotheses on the general human mobility pattern, the site function and its status in the territory. 


\subsection{Mobility pattern}

- Economic and territorial pattern

Even if, at that stage of the study, lithics and faunal remains are not analysed at the same stratigraphic resolution level, we could however begin the first discussion about the economic general pattern of the unit II occupations.

Generally, Ramandils settlements seems to be linked to the exploitation of the tertiary flint sources of the Narbonne-Sigean Basin (fig. 16). Raw material origins are mainly from the semi-local area (between 5 and $20 \mathrm{~km}$ ) around the site. Excepted the jasper, the unique raw material imported from the remote area $(35 \mathrm{~km})$, every raw material came from the surrounding of the site between $7 \mathrm{~km}$ and $17 \mathrm{~km}$. Flint were principally extracted from the tertiary outcrops of Sigean, Presqu'île du Doul, Portel des Corbières, Hameau du lac. More rarely some cherts were exploited a little further from the cretaceous and jurassic outcrops and the others kind of raw material were collected in the Aude alluvial deposits (quartz, quartzite and sandstone...) at the north of the site or sometimes on the beach deposits, just near the cave.

Despite this semi-local procurement pattern, which would rather indicate a strong and well organized exploitation in this area, the punctual arrival of jasper from the Roussillon plain, at $35 \mathrm{~km}$ south of the site, seems to indicate that groups had an important mobility on the territory and they import punctually materials of interest from these more remote areas that they browse probably for others activities.

Moreover, the faunal acquisition is more oriented towards all the available environments around the sites (Rusch et al., 2019). Main species, dominated by red deer and horse, highlight grassland with forests, which could be situated less than $5 \mathrm{~km}$ around the cave. Marine shells recorded throughout the sequence involve a transport into the site of less than $1,4 \mathrm{~m}$, compared to the current coast. Further studies will allow us to understand the use or consummation strategies of these remains. Furthermore, ibex remains found in this unit involve a rocky environment, located at least in the semi local area between 5 and $20 \mathrm{~km}$ (fig. 8 ), because we could hypothesize that ibex were situated on the nearest reliefs of the Corbières massif.

The local area seems to be exploited for its subsistence resources while semi local area provided more than $99 \%$ of the lithic raw material used and occasionally this area is exploited for the acquisition of ibex (fig. 16).

This pattern is different from the regional Mousterian sites like Crouzade Cave on the cretaceous Clape massif near Narbonne (Saos et al., in press) and Hortus site on the Montpellier region (Lebègue et al., 2010) which are characterised by a mainly local and semilocal flint and animal resources supply but completed with an additional allochthonous lithic raw material generally coming from more than $80 \mathrm{~km}$ away. These occupation sites are interpreted as short terms hunting camp or seasonal camps (Grégoire, 2012). 


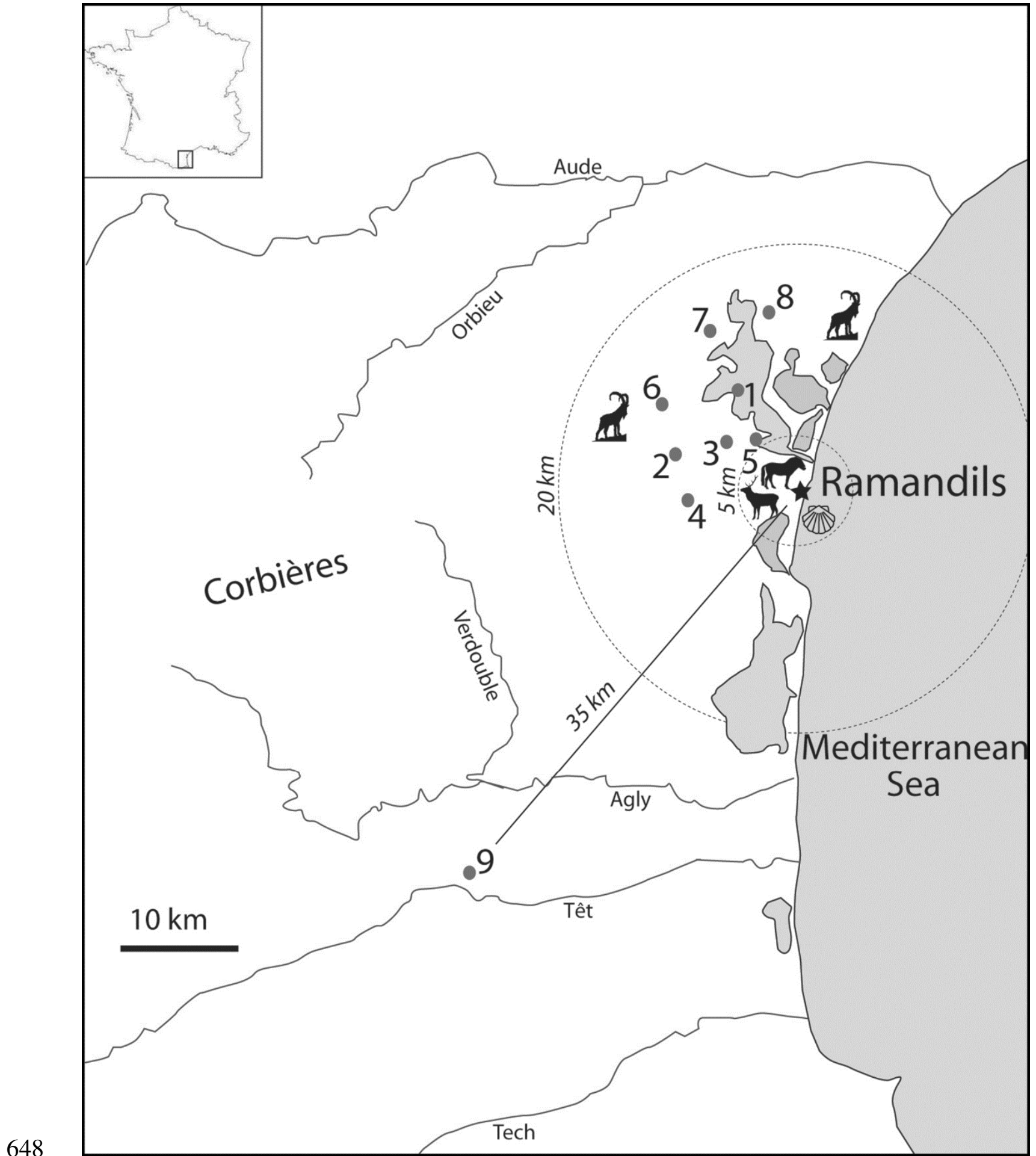

Fig. 16: Economic exploitation territory divided in: local-0 to $5 \mathrm{~km}$, semi-local-5 to $20 \mathrm{~km}$, and remote area-more than $20 \mathrm{~km}$, including lithic sources and potential location of the main species exploited as food resources.

We must go to the Ardèche region, more than $250 \mathrm{~km}$ north of Ramandils Cave, at Saint Marcel Cave, to find a Middle Palaeolithic site where the economic mobility pattern is similar (Moncel et al, 2004, Daujeard \& Moncel, 2010), with a semi-local supply, oriented on flint procurement, that not exceed $10 \mathrm{~km}$. The different occupations phases of this site, more or less contemporaneous than the Ramandils settlements, are qualified by the authors as "long term residential camp" thanks to the exploitation and consumption strategies, the lithic remains density and the topographic situation for example. 
In the case of Ramandils cave, arrival of allochthonous raw material testify probably of a 659 logistic mobility (Binford, 1980) from areas exploited for their own resources, to a base-camp 660 (Ramandils?) where natural shelter, water source, faunal abundance from various ecosystems (grassland, forest, mountain, and sea with marine shells), proximity of flint sources and of the shore, makes this place attractive and justify the frequency and the persistence of the settlement. This mobility pattern indicates a territorial economic organization where Ramandils site would take a central place and could work like an aggregation site (Kuhn, $1995)$ within an economic territory of a $35 \mathrm{~km}$ radius.

The large quantity of lithic material and the complete reduction sequence on flint testify to an intense production activity on the site during the unit II settlement. The abundance of small artefacts resulting from (i) a first massive production of small flakes, recycled in many cases as matrix for (ii) a second phase of flake production, tend to indicate that Ramandils cave seems to be a production site dependent on nearby flint sources which could be interpreted as a long term settlement because of the production strategies.

Indeed, from the techno-economic point of view, a general overview of the unit II allows to say that the groups strongly occupied the local and semi-local territory (fig. 16) and, at the same time, carried out intensive lithic production activities on the cave. This intensive activity is also noticeable thanks to the "ramification" process (Bourguignon et al., 2004) in the flake production. These facts, added to the previous one, are also in favour of the long term residential camp.

On the other hand, the incomplete reduction sequence for almost nine raw materials other than flint, but less represented, as well as the very punctual contribution of jasper by artefacts at the end of the reduction sequence, seems to demonstrate, that lithic pieces were circulating easily on the territory, and that the production, with these secondary raw materials, was very fragmented in space and time (Bourguignon et al., 2006) which is to say that people circulate a lot between different points of the territory. These facts could be in favour of a logistic mobility from the residential camp, to more specialised camps and support the assumption that Ramandils cave could be used as a long term residential camp connected with others specialized sites, one of which could be in the jasper supply area.

\subsection{Site function in unit II}

By taking account of this first results, on faunal and lithic exploitation, intrinsic to the Mediterranean coastal context (climate, topography, ecosystems, raw material available, human groups, etc.), it is possible to propose two hypotheses of occupation site modes (tab. 11). Indeed, several criteria tend to support long-term camps, nevertheless, some data seem to favour in short-term repeat occupation, compared to Upper Pleistocene sequences from southern France such as those in northwestern Mediterranean coast and in Rhone Valley (Daujeard \& Moncel, 2010; Daujeard et al, 2011, 2012, 2016; Magniez, 2010; Saos et al., 2016). 
In unit II levels, humans are the principal agents of the input and exploitation of ungulate carcasses, likewise in long-term occupations, such as in Saint-Marcel, Baume des Peyrards and Abri du Maras. However, large mammal spectrum highlights two main species, attributed to red deer and horse, with less than 50\% NISP, and various secondary ungulates with European wild ass, aurochs, and wild boar. Moreover, carnivore activities are recorded within (S10, S11, S12) and between (S12a, S13a) these levels, with young individuals, coprolites deposits, butchery and carnivore tooth-marks found on the same species (red deer and horse), which could support the hypothesis of short-term occupations.

Faunal studies indicate hominin occupations during each seasonal period of the year, with varied acquisition strategies according to the taxa and more frequent slaughtering during autumn and spring. In all levels, cervids were systematically hunted during autumn, whereas equids were killed during almost each season (in S11 and S10), with a focus on European wild ass during winter. Seasonal acquisition strategies are recorded in several Pleistocene sites such in the Rhone Valley (Daujeard \& Moncel, 2010; Daujeard et al, 2016), at Baume des Peyrards, where ibex and most of the secondary species were hunted during the cold season and summer, whereas horse was the only one killed during spring, or at Saint-Marcel, where the fallow deer from level u seems frequently hunted during spring and autumn. Periodic recurrence, according to taxa in Ramandils sequence, could imply a planned seasonal exploitation of the territory, mainly concentrated on local and semi local area, also observed by the studies on raw material procurement.

In unit II levels, adult and young ungulates are the highest classes, followed by sub-adult group, while older individuals have lower rates. Slaughtering is therefore generally aimed at the most profitable prey that could suggest the capture of females (adult individuals) and their young and can be interpreted as a human characteristic of primary and immediate access to the animals (Gaudzinski \& Roebroeks, 2000; Klein \& Cruz-Uribe, 1984; Stiner, 1994). Nevertheless, it is important to note that only young and young adults were considered for estimating seasonality. There is a chance that adults could have been hunted during different events and therefore, different seasons. However, age at death was mainly estimated through dental eruption pattern and almost only on isolates teeth.

As at Payre, at Baume Flandin and Le Figuier, (Daujeard \& Moncel, 2010; Daujeard et al., 2016), several transport strategies and butchery processes have been observed for the various ungulates. A differential degree in carcass treatment according to the species is observed in unit II levels of Ramandils Cave. Red deer, reveal most of the hominins action, rarest for secondary ungulates. Main species were almost systematically brought back whole, dismembered, filleted, and broken for an intensive bone marrow recovery, whereas secondary species are mainly represented by skull and limb end. Skinning process is generally scarce and the lack of third phalanges (except for wild boar and fallow deer) could indicate a first butchery step on the kill site. Furthermore, the scarcity of retouchers in these levels show a low technological applications of bones, usually higher for long term residential camps

735 (Daujeard et al., 2018). 
Combustion structures are not recorded while numerous burnt flint and bones, with high degrees, show fire was intensely used as well as for long-term occupation sites. Hearths could be located in not excavated area or might not be preserved, especially in the eroded area on the front of the cave, caused by an active natural spring (fig. 2). Heated and burnt remains could therefore result of secondary deposits from hearth cleaning activities. The hypothesis of bone grease exploitation or the use of bones as fuel is not exclude, further studies would allow us to explain the low proportion of cancellous bone and percussion marks.

Lithics evidence are rather in favour of the hypothesis of the long term pattern with the high quantity of lithic remains, the intensive flake production in situ with a complete flint reduction process, added to the mainly semi-local supply that requires travel between 7 and 17 $\mathrm{km}$ for supplies and replenishment (tab. 11). However, the short term pattern cannot be totally dismissed supporting by some criteria which indicate a great mobility in the territory like the incomplete reduction sequence for 9 secondary raw materials and the punctual arrival of jasper from $35 \mathrm{~km}$ away (fig. 8). In order to go further, it would be necessary to refine lithic studies with the same stratigraphic resolution level as for faunal remains.

All these criteria (tab. 11) led us to discuss the status of the site in terms of duration of occupation according to the episodes identified in unit II by archeostratigraphy. All the criteria carrying an information about seasonality, about intensive presence on the site or on the contrary about displacement on the territory were used to evaluate arguments in favour of the two hypotheses tested on this work: the long term residential camp and the short term regular hunting camp. These two categories were chosen to be compared with other studies conducted in South of France, in the same region (Lebègue et al., 2010; Magniez, 2010; Grégoire, 2012; Saos et al., in press) or in the near Rhône valley (Daujeard \& Moncel., 2010; Daujeard et al., in Djindjian et al., 2018).

However, the site function can also be thought of in terms of activities. Through the lithic toolkit of unit II it is difficult to identify any specialised activities because of the low percentage of flake tools stayed on the site and the absence of traceology study. On the other hand, the large quantity of non-retouched small debitage products and the identification of several and ramified reduction sequences, testify to an intense activity of flint blanks production of which a large part could be exported in the form of retouched tools. The nonimmediate proximity of the tertiary flint sources could testify that the site was selected for its position in relation to these lithic resources to develop easily a flake production activity but also for the immediate proximity of various subsistence resources for the group supplying, during the flint exploitation and production activity. Indeed, despite the relative prevalence of red deer and horse, faunal studies do not show specialised hunting in unit II levels according to taxa or age class. Carcasses were intensely exploited for meat and especially for bone marrow with the high use of fire for various burning degree. These data tend to indicate a consumption of available faunal resources around the cave, supporting by leporid (Morin et $a l, 2019$ ) and marine shell exploitation (Cataliotti-Valdina in Boutié, 1990; Celiberti \& Moigne in Saos et al., 2016). 


\begin{tabular}{|c|c|c|}
\hline $\begin{array}{l}\text { Hypothesis } \\
\text { of sites function }\end{array}$ & $\begin{array}{l}\text { Long-term } \\
\text { Residential camps }\end{array}$ & $\begin{array}{l}\text { Short-term } \\
\text { regular hunting camps }\end{array}$ \\
\hline $\begin{array}{l}\text { Agents of bone } \\
\text { accumulations }\end{array}$ & $\begin{array}{l}\text { Accumulation of herbivores is mainly due to } \\
\text { hominin activity and carnivore tooth-marks are always } \\
\text { less than } 4 \% \text { of the total remains. }\end{array}$ & $\begin{array}{l}\text { Butchery and carnivore tooth-marks are found on } \\
\text { the same species: mainly red deer and horse. } \\
\text { Coprolite levels in S13a and S12a }\end{array}$ \\
\hline Animal spectrum & - & $\begin{array}{l}\text { Main species }<50 \% \text { NISP, } \\
\text { with various secondary species }\end{array}$ \\
\hline Seasonality & $\begin{array}{l}\text { All year round (especially in } \mathbf{S 1 1} \text { and } \mathbf{S 1 0} \text { ), with most } \\
\text { slaughters occurring during the autumn and spring. }\end{array}$ & Varied acquisition strategies according to the taxa. \\
\hline $\begin{array}{l}\text { Acquisition } \\
\text { strategies for } \\
\text { animal resources }\end{array}$ & $\begin{array}{l}\text { Slaughtering is mainly made up of young animals } \\
\text { and adults, may be Killed in herds and corresponding to } \\
\text { females and their young (most profitable prey) }\end{array}$ & - \\
\hline $\begin{array}{l}\text { Carcass transport } \\
\text { strategies }\end{array}$ & - & $\begin{array}{l}\text { Transport strategies and access to carcasses vary } \\
\text { according to the taxa. } \\
\text { - Main ungulates: whole } \\
\text { - Secondary ungulates: partial with poorest pieces } \\
\text { (essentially skull and limb ends) }\end{array}$ \\
\hline Butchery & $\begin{array}{l}\text { Intensive and generalised butchery sequence for } \\
\text { consumption (meat and bone marrow) }\end{array}$ & $\begin{array}{l}\text { More complete butchery sequence for big and } \\
\text { medium size ungulates and scarce human occurrences } \\
\text { for poorest pieces of some others (carnivores share ?) }\end{array}$ \\
\hline Fire & $\begin{array}{l}\text { Numerous heated (low degree) and burnt bones } \\
\text { (high degrees) with burnt lithic artefacts. }\end{array}$ & - \\
\hline Bone industry & - & Scarce retouchers \\
\hline $\begin{array}{l}\text { Origin of the lithic } \\
\text { raw material }\end{array}$ & Mainly semi-local, between 7 and $17 \mathrm{~km}$ & Punctual arrival of jasper from $35 \mathrm{~km}$ away \\
\hline $\begin{array}{l}\text { Chaîne opératoire } \\
\text { according to raw } \\
\text { material }\end{array}$ & $\begin{array}{l}\text {-Complete for flint, partial for other raw material } \\
\text {-Ramification process on flint }\end{array}$ & partial reduction sequence for secondary raw material \\
\hline$\%$ of tools & Low & - \\
\hline $\begin{array}{l}\text { Lithic remains } \\
\text { density }\end{array}$ & high & - \\
\hline $\begin{array}{l}\text { Specialization } \\
\text { degree of lithic } \\
\text { production }\end{array}$ & Low & - \\
\hline $\begin{array}{l}\text { Instance for } \\
\text { Middle Palaeolithic } \\
\text { sites }\end{array}$ & $\begin{array}{l}\text { Moula (XV, XIV), Abri du Maras, Saint-Marcel, } \\
\text { Baume Néron, Baume Vallée, Mandrin (Daujeard \& } \\
\text { Moncel, 2010, Daujeard et al., in Djindjian et al., 2018) }\end{array}$ & $\begin{array}{l}\text { Orgnac 3, Saint-Anne, Payre, Baume Flandin, Baume } \\
\text { de Gigny, Figuier, Baume Moula VIII, IV (Daujeard et al., } \\
\text { in Djindjian et al., 2018) } \\
\text { Tournal (Magniez, 2010) Hortus (Lebègue et al., } \\
\text { 2010), Crouzade (Saos et al, in press) }\end{array}$ \\
\hline
\end{tabular}

Tab. 11: Zooarchaeological and lithic criteria to define types of occupation in unit II from Ramandils with instance of Middle Palaeolithic site in Mediterranean coast and the Rhône Valley (Daujeard \& Moncel, 2010; Daujeard et al., in Djindjian et al., 2018; Lebègue et al., 2010; Magniez, 2010; Saos et al., 2016, in press). 
Our attempt with this paper was to present the first results of zooarchaeological studies in unit II, subdivided by an archaeostratigraphical approach, into several levels. These spatial analyses allowed us, for the first time, to individualize coprolite beds, produced by carnivores, between human occupation levels, permitting to indicate recurrent periods when Neanderthals did not occupy the site and then allow us to better identify periods of anthropic settlements.

A rich archaeological material is highlighted in three archaeostratigraphic levels with numerous lithic industries and high proportion of burnt bones. Periods of continuing human presence have therefore influenced the taxonomic profile, reflecting planned exploitation of seasonally available resources, as well as more opportunistic behaviours represented by the procurement of mainly semi local raw materials within a $20 \mathrm{~km}$ radius territory. This apparent opportunism could be explained by the fact that the tertiary flint, despite an ordinary quality, had to perfectly correspond to the needs of the hominins.

The intensive human activities on these anthropic levels (tab. 11), could indicate long term occupations all year round long with slaughtering of most profitable prey, various butchery steps and numerous lithic artefacts, burnt flint and bones with high burning degree. Nevertheless, several features tend to represent recurrent short-term occupations (tab. 11) with various prey slaughtered, seasonal hunting according to taxa, a differential degree in carcass treatment according to the species, the partial reduction sequences for 9 lithic raw materials. Despite the rare occurrence of carnivore marks, less than $4 \%$ of total NR, tooth marks affect the same species which are exploited by humans, inducing prompt scavenging during human abandonment of the cave. Moreover, coprolite deposits within and between unit II levels, on well-defined areas, highlighted by archaeostratigraphical studies, might likewise indicate periods when human groups were not occupying the cave.

This multidisciplinary approach permits to highlight the difficulty, for the unit II level of Ramandils cave, of deciding between two hypotheses of function site, related to the duration of occupation and the activities carried out. Indeed, arguments in favour of the two patterns were identified and others seems to be necessary to conclude.

To go further, raw material and lithic artefacts studies, performed first on the whole unit II, 810 with the aim to define, for each antropic occupation, the exploited teritery 811 functional or technical objectives of the settlement. However, a mobility pattern is highlighted 812 by this study indicating an economic organization within a $35 \mathrm{~km}$ radius territory of littoral 813 plain, where Ramandils site take probably a central place on Mediterranean coast according to 814 the high human presence recorded on the site and the economic and subsistence modalities 815 observed. 
817 We would like to thank the organizers of the XVIII ${ }^{\text {th }}$ UISPP World Congress and the 818 Scientific Committee members. We are very grateful to Camille Daujeard and the anonymous 819 reviewer for their constructive comments on this manuscript. This work is supported by a 820 doctoral grant $n^{\circ}$ 2016-10-D.544 from University of Perpignan Via Domitia in the context of 821 a PhD thesis. The French Ministry of Culture also supported the Collective Research Project, 822 PCR: "Le monde moustérien entre Rhône et Pyrénées", dir. T. Saos 2015-2021 (Team 1, 823 UMR 7194-MNHN-UPVD-CERP Tautavel), including Ramandils study.

\section{References}

825 Azorit, C., Analla, M., Carrasco, R., Calvo, J. R., Muñoz-Cobo, J., 2002. Teeth eruption pattern 826 in red deer (Cervus elaphus hispanicus) in southern Spain. Anales de Biologia, 24, 107-114.

827 Banès, L., 1996. Les restes dentaires de la faune des grottes des Ramandils (Port-la-Nouvelle, 828 Aude) et de la Crouzade (Gruissan, Aude). Mémoire de Maîtrise, Université Paul Valéry, 829 Montpellier III, Montpellier, 135 p.

830 Banès, L., 1998. La faune moustérienne de la grotte des Ramandils. (La Nouvelle, Aude). 831 Mémoire de D.E.A., Université de Perpignan Via Domitia, Perpignan, 205 p.

832 Bearder, S.K., Randall, R.M., 1978. The use of fecal marking sites by spotted hyenas and civets. 833 Carnivore 1, 32-48.

834 Barone, R., 1999. Anatomie comparée des animaux domestiques. Tome 1 Ostéologie IVème 835 edition. Vigot, Paris, 761 p.

836 Binford, LR., 1980. Willow smoke and dog's tails: hunter-gatherer settlement systems and 837 archaeological site formation. American Antiquity, 45(1), pp. 4-20.

838 Binford, L. R., 1981. Bones: ancient men and modern myths. New York: Academic.

839 Bischoff, J.L., Rosenbauer, R.J., Tavoso, A., De Lumley, H., 1988. A test of Uranium series 840 dating of fossil tooth enamel: results from Tournal cave, France. Applied Geochemistry, 3, $841 \quad 145-151$.

842 Blumenschine, R.J., 1986. Carcass consumption sequences and the archaeological distinction of 843 scavenging and hunting. Journal of Human Evolution, 15(8), 639-659.

844 Bourguignon, L., Delagne, A., Meignen, L., 2006. Systèmes de production lithique, gestion des 845 outillages et territoires au Paléolithique moyen : où se trouve la complexité. Normes 
846 techniques et pratiques sociales. De la simplicité des outillages pré et protohistoriques 847 XXVIe. Rencontres internationales d'archéologie et d'histoire d'Antibes. Sous la direction de 848 L. Astruc, F. Bon, V. Léa, P.-Y. Milcent, S. Philibert; Éditions APDCA, Antibes, 2006.

849 Bourguignon, L., Faivre, J.-Ph., Turq, A., 2004. Ramification des chaînes opératoires : une 850 spécificité du Moustérien ? Paleo, 16, 41-61.

851 Boutié, P., 1990. La grotte moustérienne des Ramandils (Port-la-Nouvelle, Aude). Rapport de 852 fouille programmée de fin de triennale 1988-1990, Service Régional de l'Archéologie de 853 Montpellier, $85 \mathrm{p}$.

854 Boutié, P., 1993. Le gisement moustérien des Ramandils (Port-la-Nouvelle, Aude). Rapport de 855 fouille programmée, Saison 1991-1992-1993, S.R.A. of Montpellier, 41 p.

856 Boutié P., Ajaja, O., Banès, L., Molès, V., Kabiri, L., Grégoire, S., 1998. Le gisement 857 moustérien des Ramandils (Port-la-Nouvelle, Aude). Archéologie de la France-Informations, 858 Languedoc-Roussillon, [online], Languedoc-Roussillon, uploaded on 01/03/2004, consulted 859 the 23/08/2018, URL: http://journals.openedition.org/adlfi/11711, 26 p.

860 Brugal, J.-P., Fosse, P., Guadelli, J.L., 1997. Comparative study of bone assemblages made by 861 recent and Pleistocene hyenids. In : L. A. Hannus, L. Rossum \& R. P. Winham (eds) 862 Proceedings of the 1993 bone modification conference, Hot Springs, South Dakota, 158-187.

863 Brugal, J.-P., Fourvel, J.-B., Fosse, P., 2017. Premières observations sur les guides des 864 Carnivores de la grotte de l'Observatoire (Principauté de Monaco). Bulletin du Musée 865 d'Anthropologie Préhistorique de Monaco, 57, 47-60.

866 Bunn, H.T., 1983. Comparative analysis of modern bone assemblage from a San hunter-gatherer 867 camp in the Kalahari Desert, Bostwana, and from a spotted hyena den near Nairobi, Kenya. 868 BAR International Series, 163, 143-148.

869 Cáceres, I., Bravo, P., Esteban, M., Expósito, I., Saladié, P., 2002. Fresh and heated bones 870 breakage. An experimental approach. In: Rienzi, M., de Pardo Alonso, M.V., Belinchón, M., 871 Peñalver, E., Montoya P., Márquez-Aliaga, A. (Eds.), Current Topics on Taphonomy and 872 Fossilization, Valencia, 471-481.

873 Carbonell, E. Editor 2012. High resolution archaeology and Neanderthal behaviour. Time and 874 space in level J of Abric Romani (Capellades, Spain). Ed. Springer.

875 Cochard, D., Brugal, J.P., Morin, E., Meignen, L., 2012. Evidence of small fast game 876 exploitation in the Middle Paleolithic of Les Canalettes Aveyron, France. 877 Quaternary International, 264, 32-51 
878 Cornevin, C Lesbre, F.X., 1894. Traité de l'âge des animaux domestiques d'après les dents et les 879 productions épidermiques. Librairie J.-B. Baillière et fils, Paris, 462 p.

880 Costamagno, S., Beauval, C., Lange-Badré, B., Vandermeersch, B., Mann, A., Maureille, B., 881 2005. Homme ou carnivores ? Protocole d'étude d'ensembles osseux mixtes : l'exemple du 882 gisement moustérien des Pradelles (Marillac-le-Franc, Charente). Archaeofauna, 14, 43-68.

883 Crezzini, J., Boscato, P., Ricci, S., Ronchitelli, A., Spagnolo, V., Boschin, F., 2015. A spotted 884 hyaena den in the Middle Palaeolithic of Grotta Paglicci (Gargano promontory, Apulia, 885 Southern Italy). Archaeological and Anthropological Sciences, 8, 227-240. DOI 886 10.1007/s12520-015-0273-0

887 Daujeard, C., 2008. Exploitation du milieu animal par les Néandertaliens dans le Sud-Est de la 888 France. British Archaeological Reports International Series, Oxford, 1867, 634 p.

889 Daujeard, C., Moncel, M.H., 2010. On Neanderthal subsistence strategies and land use: a 890 regional focus on the Rhône Valley area in southeastern France. Journal of Anthropological 891 Archaeology, 29 (3), 368-391.

892 Daujeard, C., Abrams, G., Germonpré, M., Le Pape, J.-M., Wampach, A., Di Modica, K., 893 Moncel, M.H., 2016. Neanderthal and animal karstic occupations from southern Belgium and 894 south-eastern France: Regional or common features? Quaternary International 411, 179-197.

895 Daujeard, C., Valensi, P., Fiore, I., Moigne, A.-M., Tagliacozzo, A., Moncel, M.-H., Santagata, 896 C., Cauche, D., Raynal, J.-P., 2018. A Reappraisal of Lower to Middle Palaeolithic Bone 897 Retouchers from Southeastern France (MIS 11 to 3). In "Retouching the Palaeolithic" 898 volume, RGZM edition, Mainz, 93-132.

899 Daujeard, C., Brugal, J.P., Crégut-Bonnoure, E., Magniez, P., Moigne, A.M., Valensi, P., 2018. 900 Les comportements de subsistance au Paléolithique moyen dans le Sud-Est de la France. In 901 Djinjian F.(dir.) La Préhistoire de la France, Hermann Editions, Paris, 470 p.

902 Diedrich, C.G., 2012. Typology of ice age spotted hyena Crocuta crocuta spelaea (Goldfuss, 903 1823) coprolite aggregate pellets from the European Late Pleistocene and their significance at 904 dens and scavenging sites. In: Hunt, et al. (Eds.), Vertebrate Coprolites. 57. New Mexico 905 Museum of Natural History and Science, 369-378.

906 Discamps, E., Boudadi-Maligne, M., Chagneau, J., Armand, D., Guadelli, J.-L., Lenoir, M. 2012. 907 Ours, hommes, hyènes : qui a occupé la grotte de Bourdette (Sainte-Colombe-en-Bruilhois, 908 Lot-et-Garonne, France) ? Paléo, 23, 117-136. 
909 Domínguez-Rodrigo, M., Piqueras, A., 2003. The use of tooth pits to identify carnivore taxa in 910 tooth-marked archaeofaunas and their relevance to reconstruct hominid carcass processing 911 behaviors. Journal of Archaeological Sciences. 30, 1385-1391.

912 Fernandez Rodriguez, C., Ramil Rego, P., Martinez Cortizas, A., 1995. Characterization and 913 Depositional Evolution of Hyaena (Crocuta crocuta) Coprolites from La Valifia Cave 914 (Northwest Spain). Journal of Archaeological Science, 22, 597-607.

915 Fosse, P. 1994.- Taphonomie Paléolithique : Les grands mammifères de Soleilhac (Haute-Loire) 916 et de Lunel-Viel 1 (Hérault). PhD thesis, Université de Provence, Aix-Marseille I, 318 p.

917 Fosse, P. 1997. Variabilité des assemblages osseux créés par l'hyène des cavernes. Paleo, 9, 1591854.

919 Fourvel, J.-B. 2012. Hyénidés modernes et fossiles d'Europe et d'Afrique : taphonomie 920 comparée de leurs assemblages osseux. $\mathrm{PhD}$ thesis, Université de Toulouse-Le Mirail, 921 Toulouse 2, $615 \mathrm{p}$.

922 Fourvel, J.-B., Fosse, P., Fernandez, P., Antoine, P.O., 2014. La grotte de Fouvent, dit l'Abri 923 Cuvier (Fouvent-le-Bas, Haute-Saône, France) : analyse taphonomique d'un repaire d'hyènes 924 du Pléistocène supérieur (OIS 3). PALEO [En ligne], 25 | 2014, mis en ligne le 20 août 2015. 925 Consulté le 04 juin 2018. URL : http://paleo.revues.org/2747.

926 Gaudzinski, S., Roebroeks, W., 2000. Adults only. Reindeer hunting at the Middle Palaeolithic 927 site Salzgitter Lebenstedt, Northern Germany. Journal of Human Evolution, 38, 497-521.

928 Gerber, J.-P., 1973. Le site des Ramandils une faune du début du würmien II en Languedoc 929 méditerranéen. Bulletin de l'Association française pour l'étude du quaternaire, 10 (1), 7-12.

930 Grayson, D. K., 1984. Quantitative zooarchaeology. AcademicPress, Orlando, 202 p.

931 Grégoire, S., 2000. Origine des matières premières des industries lithiques du Paléolithique 932 pyrénéen et méditerranéen. Contribution à la connaissance des aires de circulations 933 humaines. PhD thesis, University of Perpignan, $242 \mathrm{p}$.

934 Grégoire, S., Bazile, F., Boccaccio, G., Menras, C., Pois, V., Saos, T., 2010. Les ressources 935 siliceuses en Languedoc-Roussillon. Bilan des données acquises. Silex et Territoires 936 préhistoriques. Avancées des recherches dans le Midi de la France. Actes de la Table-Ronde 937 de Lattes, juin 2008. Cahiers de Geopré $n^{\circ} 1$. 
938 Grégoire, S., 2011. Les fouilles de la famille Helena sur les sites de la région de Narbonne. In : 939 Cent ans de Préhistoire. L'institut de Paléontologie Humaine. (Lumley H. et Hurel A. Dir.), 940 CNRS Editions, 187-196.

941 Grégoire, S., 2012. Nature et évolution de l'organisation territoriale des populations 942 paléolithiques du bassin méditerranéen, mémoire d'habilitation à diriger des recherches 943 (HDR), Université de Perpignan Via Domitia, 1, 197 p., 91 figures, 26 tableaux.

944 Guadelli, J.-L., 1998. Détermination de l'âge des chevaux fossiles et établissement des classes 945 d'âge. Paléo, 10, 87-93.

946 Haynes, G., 1983a. A guide for differentiating mammalian Carnivore taxa responsible for gnaw 947 damage to herbivore limb bones. Paleobiology, 9 (2), 164-172.

948 Haynes, G., 1983b. Frequencies of spiral and green-bone fractures on ungulate limb bones in 949 modern surface assemblages. American Antiquity, 48, 102-114.

950 Hayssen, V, Van Tienhoven, A, Van Tienhoven, A, Asdell, Sa, 1993. Asdell's patterns of 951 mammalian reproduction. A compendium of species-specific data. Corner University Press, 952 New York

953 Hillson, S., 1986. Teeth. Cambridge University Press. 400 p., 954 https://doi.org/10.1002/ajpa.1330730418

955 Jouy-Avantin, F., Combes, C., Lumley (De), H., Miskovsky, J.C., Mone, H., 1999. Helminth 956 eggs in animal coprolites from a Middle Pleistocene site in Europe. Journal of Parasitology, $95785(2), 376-379$.

958 Jouy-Avantin, F., Debenath, A., Moigne, A.M., Mone, H., 2003. A standardized Method for the 959 description and the study of coprolites. Journal of Archaeological Science, 30 (3), 367-372.

960 Kabiri, L., 1993. Formations littorales et continentales du Pléistocène supérieur en Languedoc961 Roussillon et Catalogne. Étude géologique des remplissages des Ramandils (Port-la962 Nouvelle) et de l'Arbreda (Serinyà). PhD thesis, Muséum national d'Histoire naturelle, Paris, $963210 \mathrm{p}$.

964 Klein, R. G. \& Cruz-Uribe, K., 1984. The analysis of animal bones from archaeological sites. 965 Prehistoric Archeology and Ecology series, Butzer \& Freeman (Eds.), University of Chicago 966 Press, Chicago 273 p.

967 Kuhn, S. 1995. Mousterian Lithic Technology, an ecological perspective. Princeton: Princeton 968 university press. 
969 Kruuk, H., 1972. The Spotted Hyena: A story of predation and social behaviour: Chicago, 970 University of Chicago Press, 335 p.

971 Lartigot-Campin, A.-S., Moné, H., 2017. Analyses polliniques et parasitologiques préliminaires 972 de coprolithes de carnivores du site moustérien des Ramandils (Port-la-Nouvelle, Aude, 973 France). Quaternaire, 28 (2), 217-224.

974 Lebegue, F., Boulbes, N., Gregoire, S. Et Moigne, A.M. 2010. Systèmes d'occupation, 975 exploitation des ressources et mobilité des néandertaliens de l'Hortus (Hérault, France). In 976 Conard N. et Delagne A. ed. Settlement dynamics of the Middle Paleolithic and Middle Stone 977 Age. Kerns Verlag. Tubingen. III, 455-483.

978 Lebègue F., 2011 - Le Paléolithique moyen récent entre Rhône et Pyrénées : approche de 979 l'organisation techno-économique des productions lithiques, schémas de mobilité et 980 organisation du territoire (Les Canalettes, L'Hortus, Bize-Tournal, La Crouzade et La 981 Roquette II). $\mathrm{PhD}$ thesis, University of Perpignan, 797 p.

982 Lebon, M., 2008. Caractérisation par Spectroscopie Infrarouge à Transformée de Fourier des 983 ossements chauffés en contexte archéologique - Comparaison entre référentiel moderne et 984 matériel fossile, Implications diagénétiques. PhD thesis, dir. C. Falgueres, Muséum national 985 d'Histoire naturelle, Paris, 337 p.

986 Lumley, H. de, 1971. Le Paléolithique inférieur et moyen du midi méditerranéen dans son cadre 987 géologique. Paris : éditions du CNRS, Véme Supplément à Gallia-Préhistoire, tome II : Bas 988 Languedoc -Roussillon - Catalogne, 238-261.

989 Lyman, R. L., 1994. Vertebrate taphonomy. Cambridge manuals in archaeology. Cambridge 990 University Press. Cambridge, 524 p., https://doi.org/10.1017/CBO9781139878302.

991 Lyman, R.L. 2008. Quantitative Paleozoology. Cambridge University Press. 348 p., 992 https://doi.org/10.1017/CBO9780511813863.

993 Magnell, O., Carter, R., 2007. The chronology of tooth development in wild boar -A guide to 994 age determination of linear enamel hypoplasia in prehistoric and medieval pigs. Veterinarija 995 Ir Zootechnika, 40, 43-48. 
996 Magniez, P., 2010. Étude paléontologique des Artiodactyles de la grotte de Tournal (Bize997 Minervois, Aude, France). Étude taphonomique, archéozoologique et paléoécologique des 998 grands Mammifères dans leur cadre biostratigraphique et paléoenvironnemental. $\mathrm{PhD}$ thesis, 999 University of Perpignan Via Domitia, Perpignan, 1, 916 p.

1000 Mallye, J.-B., Thiébaut, C., Mourre, V., Costamagno, S., Claud, E., Weisbecker, P., 2012. The 1001 Mousterian bone retouchers of Noisetier Cave: experimentation and identification of marks. 1002 Journal of Archaeological Sciences, 39, 1131-1142.

1003 Mariezkurrena, K., 1983. Contribución al conocimiento del desarrollo de la dentición y el 1004 esqueleto post-craneal de Cervus elaphus. Munibe, 35, 149-202.

1005 Mills, M.G.L. 1990. Kalahari hyaenas: the comparative behivioural ecology of two species. 1006 Chapman \& Hall, London, 304 p.

1007 Moigne, A.M., 1983. Taphonomie des faunes quaternaires de la Caune de l'Arago, Tautavel. $1008 \mathrm{PhD}$ thesis, Université Pierre et Marie Curie, Paris-6, 344 p.

1009 Moles, V., 2008. Étude techno-économique et typologique des industries de la grotte des 1010 Ramandils (Port-la-Nouvelle, Aude, France). Contribution à la reconnaissance d'une 1011 microproduction au Paléolithique moyen. PhD thesis, Université Paul Valéry, Montpellier III, 1012 Montpellier, 375 p;

1013 Moncel, M.H., Daujeard, C, Cregut-Bonnoure, E, Fernandez, P, Faure, M, 2004. L'occupation de 1014 la grotte de Saint-Marcel (Ardèche, France) au Paléolithique moyen: stratégie d'exploitation 1015 de l'environnement et type d'occupation de la grotte. L'exemple des couches I, J, et J'. Bulletin 1016 de la Société préhistorique française 101 (101), 257-304

1017 Morin, E., 2007. Fat composition and Nunamiut decision-making: a new look at the marrow and 1018 bone grease indices. Journal of Archaeological Science, 34, 69-82.

1019 Morin, E., 2010. Taphonomic implications of the use of bone as fuel. Palethnologie, 2, 209-217.

1020 Morin, E., Meier, J., Guennouni, K. El, Moigne, A.-M., Lebreton, L., Rusch, L., Valensi, P., 1021 Conolly, J., Cochard, D., 2019. New evidence of broader diets for archaic Homo populations 1022 in the northwestern Mediterranean. Science Advances, 5 (3), doi : 10.1126/sciadv.aav9106.

1023 Noe-Nygaard, N, 1989. Man-made trace fossils on bones. Journal of Human Evolution, 4, 4611024491.

1025 Oliver, J.S., 1993. Carcass processing by the Hadza: bone breakage from butchery to 1026 consumption. In: Hudson, J. (Ed.), From Bones to Behavior: Ethnoarchaeological and 
1027 Experimental Contributions to the Interpretation of Faunal Remains. Occasional Paper 21.

1028 Southern Illinois University, Center for Archaeological Investigations, Carbondale, IL, 2001029 227.

1030 Pales, L., Garcia, M.A., 1981. Atlas ostéologique pour servir à l'identification des mammifères 1031 du quaternaire. Herbivores, II - tête, rachis, ceintures scapulaires et pelviennes, membres. 1032 CNRS Edition, Paris, 1-177.

1033 Patou-Mathis, M., 2000. Neanderthal subsistence behaviours in Europe. International Journal of 1034 Osteoarchaeology 10, 379-395.

1035 Percie Du Sert, C., 1992. Les lagomorphes du gisement moustérien des Ramandils (Port-La1036 Nouvelle, Aude). Mémoire de maîtrise, Université Paul Valéry, Montpellier III, Montpellier, $1037116 \mathrm{p}$.

1038 Pérez Ripoll, M., 1988. Estudio de la secuencia de desgaste de los molares de la Capra 1039 Pyrenaica de yacimientos prehistóricos. Archivo de Prehistoria Levantina, 17, 83-127.

1040 Pineda, A. Saladié, P. Expósito, I., Rodríguez-Hidalgo, A., Cáceres, I., Huguet, R., Rosas, A., 1041 López-Polín, L., Estalrrich, A., García-Tabernero, A., Vallverdú, J., 2017. Characterising 1042 hyena coprolites from two latrines of the Iberian Peninsula during the Early Pleistocene: Gran 1043 Dolina (Sierra de Atapuerca, Burgos) and La Mina (Barranc de la Boella, Tarragona). 1044 Palaeogeography, Palaeoclimatology, Palaeoecology, 480, 1-17.

1045 Pois, V., 1998. La Caune de l'Arago (Pyrénées-Orientales) : Visualisation spatiale, en coupe et 1046 en plan, du matériel archéologique par interrogation de la "Base de Données Matériel 1047 Paléontologique et Préhistorique". Conséquences sur l'interprétation du mode de vie de 1048 l'Homme de Tautavel. Thèse de Doctorat du Mus. Nat. d'Hist. Nat., 2 tomes, 425 p.

1049 Pois, V., 1999. Le niveau archéologique I/J de la Caune de l'Arago à Tautavel (Pyrénées1050 Orientales). Mise en évidence d'un horizon à ossements d'ours de Deninger. C. R. Acad. Sci., 1051 Paris, IIa, ,533-536.

1052 Pois, V., 2000. Habitats préhistoriques au Paléolithique inférieur. Etude de l'ensemble II de la 1053 Caune de l'Arago (Tautavel, Pyrénées-Orientales, France). Quaternaire, 11(3/4), 187-196.

1054 Poplin, F., 1981. Un problème d'ostéologie quantitative : calcul effectif initial d'après 1055 appariements. Généralisation aux autres types de remontages et à d'autres matériels 1056 archéologiques. Revue d'Archéométrie, 5, 159-165.

1057 Potts, R.B., Shipman, P., 1981. Cutmarks made by stone tools on bones from Olduvai Gorge, 1058 Tanzania. Nature, 291, 577-580. 
1059 Rendu, W., 2007. Planification des activités de subsistance au sein du territoire des derniers 1060 Moustériens. Cémentochronologie et approche archéozoologique de gisements du 1061 Paléolithique moyen (Pech-de-l'Azé I, La Quina, Mauran) et Paléolithique supérieur ancien 1062 (Isturitz). PhD thesis, University of Bordeaux 1, 352 p.

1063 Rosell, J., Blasco, R., Huguet, R., Caceres, I., Saladie, P., Rivals, F., Bennasar, M., Bravo, P., 1064 Campeny, G., Esteban-Nadal, M., Fernandez-Laso, M.C., Gabucio, J., Ibañez N., Martin, P., 1065 Muñoz, L., Rodriguez-Hidalgo, A., 2012. Occupational Patterns and Subsistence Strategies in 1066 Level J of Abric Romaní, In: Carbonell, E. (Ed.), High Resolution Archaeology and 1067 Neanderthal Behavior: time and space in level J of Abric Romaní (Capellades, Spain). 1068 Springer, 2(8), 313-372.

1069 Rusch, L., Boulbes, N., Lartigot-Campin, A.-S., Pois, V., Testu, A., Bahain, J-J., Falguères, C., 1070 Shao, Q., Moigne, A.-M., Saos, T., Boutié, P., 2019. Contexte paléoenvironnemental et 1071 chronologique des occupations néandertaliennes de la grotte des Ramandils (Port-la-Nouvelle, 1072 Aude, France). Apport des restes de grands mammifères. Quaternaire.

1073 Saladié, P., Rodríguez-Hidalgo, A., Marín, J., Vallverdú, I, Poch, J., Carbonell, E., 2018. The top 1074 of the Gran Dolina (Atapuerca, Spain) sequence: A zooarchaeological and occupational 1075 perspective. Quaternary Science Reviews, 195, 48-71

1076 Saos, T, 2003. Cadre stratigraphique paléoclimatique et géochronologique du Languedoc1077 Roussillon au cours du Pléistocène supérieur d'après l'étude des remplissages de grottes. 1078 Thèse de doctorat en Géologie du Quaternaire de l'Université de Perpignan, 253 p.

1079 Saos, T., Grégoire, S., Bahain, J.J., Higham, T., Moigne, A.M., Testu, A., Boulbes, N., 1080 Bachellerie, M., Chevalier, T., Becam, G., Duran, J.P., Alladio, A., Ortega, M.I., Deviese, T., 1081 Xiao, Q., in press The Middle and Upper Palaeolithic of la Crouzade cave (Gruissan, Aude, 1082 France): New excavations and a chronostratigraphic framework. Quaternary International.

1083 Saos, T., Grégoire, S., Moigne, A.-M., Testu, A., Boulbes, N., Perrenoud, C., Pois, V., Rusch, L., 1084 Lartigot-Campin, A.-S., Chevalier, T., Becam, G., Lebreton, L., Celiberti, V., Alladio, A., 1085 Bachellerie, M., Milizia, C., Bahain, J.-J., Falguères, C., Voinchet, P., Shao, Q., Elalouf, J.1086 M., Marsolier-Kergoat, M.-C., Moncel, M.-H., Bourguignon, L., Chacón Navarro, M.G., 1087 Barsky, D., Magniez, P., Molès, V., Duran, J.-P., Ivorra, J., Dainat, D., 2016. Le Monde 1088 moustérien méditerranéen entre Rhône et Pyrénées. Rapport 2016 du Programme Collectif de 1089 Recherches, bilan triennal 2014-2016, Service Régional de l'Archéologie de Montpellier., $1090237 \mathrm{p}$.

1091 Saos, T., Moigne, A.-M., Testu, A., Boulbes, N., Rusch, L., Lartigot-Campin, A.-S., Bachellerie, 1092 M., Bahain, J.-J., Falgueres, C., Shao, Q., Chacon Navarro, M. G., Milizia, C., Dainat, D., 1093 2017. Le monde moustérien méditerranéen entre Rhône et Pyrénée. Rapport 2017 du 
1094 Programme Collectif de Recherches. Rapport intermédiaire 2017, triennal 2017-2019, S.R.A. 1095 de Montpellier, 58 p.

1096 Schimd, E., 1972. Atlas of Animal Bones for Prehistorians, Archaeologists, and Quaternary 1097 Geologists. Elsevier Science Publishers, Amsterdam, London, New York, 160 p.

1098 Shipman, P., Rose, J.J., 1983. Cut mark mimics on modern and fossil bovid bones. Current 1099 Anthropology, 25, 116-117.

1100 Speth, J.D., Meignen, L., Bar-Yosef, O., Goldberg, P., 2012. Spatial organization of Middle 1101 Paleolithic occupation $\mathrm{X}$ in Kebara Cave (Israel): Concentrations of animal bones. 1102 Quaternary International, 247, 85-102.

1103 Stiner, M.C. 1990. The Use of Mortality Patterns in Archaeological Studies of Hominid 1104 Predatory Adaptations. Journal of Anthropological Archaeology, 9, 305-351.

1105 Stiner, M.C., 1994. Honor Among Thieves: A Zooarchaeological Study of Neandertal Ecology. 1106 Princeton University Press, Princeton, 447 p.

1107 Szmidt, C., 2003. The Mousterian in Mediterranean France e a Regional, Integrative and 1108 Comparative Perspective. In: British Archaeological Reports International Series, S1147, $1109305 p$.

1110 Valladas, H., Joron, J.-L., 1993. Application de la méthode de datation par la 1111 thermoluminescence à l'abri des Canalettes. In: Meignen, L. (Ed.), L'Abri des Canalettes. Un 1112 Habitat Moustérien sur les Grands Causses (Nant, Aveyron). CNRS Editions, Paris, 41-146.

1113 Valensi, P., Psathi, E., 2004 - Faunal exploitation during the Middle Palaeolithic in south-eastern 1114 France and north-western Italy. International Journal of Osteoarchaeology, 14, 256-272.

1115 Varela, S., Rodríguez, J., 2004. Atlas osteológico de carnívoros ibéricos. MNCN, 1-70.

1116 Villa P, Mahieu, E, 1991. Breakage patterns of human long bones. Journal of Human Evolution, $1117 \quad 21,27-48$.

1118 Vivent, D., 1989. Analyses polliniques de coprolithes d'hyenes de deux sites paléolithiques 1119 d'Auvergne (Saint-Hippolyte, Puy-de-Dôme et Châtelperron, Allier). Revue archéologique du 1120 Centre de la France, 28 (2), 229-235.

1121 Yokoyama, Y., Nguyen, H.-V., Quaegebeur, J.-P., Jean-Pierre, F., 1987a. Datation par la 1122 spectrométrie gamma non destructive et la résonance de spin électronique (E.S.R.) du 1123 remplissage de la grotte Tournal à Bize (Aude). Cypsela 6, 145-149. 
1124 Yokoyama, Y., Nguyen, H.V., Shen, G., Quaegebeur, J.P., Koumba, N., 1987b. Datation par les 1125 méthodes des familles de l'Uranium et la résonance de spin électronique (ESR) du 1126 remplissage de la grotte des Ramandils à Port-la-Nouvelle (Aude, France). Cypsela, 6, 1511127154. 